\title{
Who Benefited from Trade Liberalization in Mexico? Measuring the Effects on Household Welfare ${ }^{\otimes}$
}

\author{
Alessandro Nicita ${ }^{*}$
}

\section{World Bank Policy Research Working Paper 3265, April 2004}

The Policy Research Working Paper Series disseminates the findings of work in progress to encourage the exchange of ideas about development issues. An objective of the series is to get the findings out quickly, even if the presentations are less than fully polished. The papers carry the names of the authors and should be cited accordingly. The findings, interpretations, and conclusions expressed in this paper are entirely those of the authors. They do not necessarily represent the view of the World Bank, its Executive Directors, or the countries they represent. Policy Research Working Papers are available online at http://econ.worldbank.org.

Keywords: Trade and Poverty, Households, Pass-through, Earnings, Mexico JEL Classification: D1, F1, J3, R2

\footnotetext{
${ }^{\otimes}$ I wish to thank Jaime de Melo, Marcelo Olarreaga, Guido Porto, Isidro Soloaga and, David Tarr for helpful comments and discussion, although they are not responsible for any errors remaining. * Development Research Group, Trade (DECRG-TR), World Bank, 1818 H Street, NW, Washington DC 20433, email: anicita@worldbank.org.
} 


\begin{abstract}
This study performs an ex-post analysis of the effects of the trade liberalization in Mexico between 1989 and 2000, taking into account regional differences in the Mexican economy. The effects of trade liberalization are first translated into changes in regional prices and wages. Those estimates are plugged into a farm-household model to estimate the effect on households' welfare.
\end{abstract}

The findings suggest that trade liberalization has affected domestic prices and labor income differently both across income groups and geographically across the country, hence producing diverse outcomes on different households. Regarding prices, the results indicate that trade liberalization has lowered relative prices of most non-animal agricultural products and, while reducing the cost of consumption, has reduced households' agricultural income, so widening the income gap between urban and rural areas. The findings also shows that trade liberalization has had diverse effects on wage rates. Skilled workers, for which trade liberalization has produced an increase in wages, have benefited relative to unskilled workers. Wages of unskilled workers have in many regions decreased as a result of trade liberalization. Similar differences are found in the geographic distribution of the benefits of trade liberalization, with the states closest to the United States border gaining threefold more relative to the least developed states in the south. Therefore trade liberalization, although beneficial, has contributed to increase in inequality between the south and the north of the country, urban and rural areas, and skilled and unskilled labor.

From a poverty perspective, the trade liberalization that occurred between 1989 and 2000 has had the direct effect of reducing poverty by about 3 percent, therefore lifting approximately 3 million individuals out of poverty. 


\section{Introduction}

While economic theory has long advocated openness to trade as an important element of sound economic policy, the empirical evidence on the actual effects of trade liberalization on income distribution and welfare have been difficult to measure. Recently, the debate on the effects of globalization on poverty has rekindled the debate. At an analytical level, it is recognized that one must trace through the effects of trade policy changes on household welfare via the price transmission mechanism (say how much of the tariff reduction gets translated into changes in households' disposable income), via effects on household earnings (significant trade policy changes have general equilibrium repercussions via adjustments in factor markets), and via adjustments in the public sector (tariff revenue changes). It is also recognized that effects will not be evenly spread across the economic landscape, i.e., regional effects are likely to be important, as some regions will be isolated from the effects of changes in trade policy (often regions where markets are not developed and where the poor are concentrated). McCulloch et al. (2002) give a thorough description of these transmission channels.

In the past, two approaches have been used to try to identify the effects of trade policy changes on income distribution and poverty at the household level: ex-ante simulations and ex-post econometric analysis based on household survey data. This paper belongs to this latter category which goes back to Deaton (1989). ${ }^{1}$ Recent work in that tradition includes Levinshon (1999), Edmonds and Pavcnik (2003), Goldberg and Pavcnik (2003) and Porto (2003). The distinctive feature of this paper, spelled out below, is the availability of a half-dozen household surveys spanning virtually the entire period of trade liberalization in Mexico. Arguably the analysis of such a dataset allows for a much better identification of the likely effects of trade liberalization on household welfare. I provide estimates of the effects of Mexican trade liberalization throughout the 1990s, relying on six household surveys spanning the period 1989 to 2000, with transmission effects of changes in trade policy being calculated on the basis of 12 important commodities in the consumption basket of Mexican households.

\footnotetext{
${ }^{1}$ Reimer, 2002, offers a review of the literature.
} 
In relation to previous work in this tradition, this paper goes beyond the previously cited studies in several dimensions. First, welfare estimates take into account both the adjustments in the expenditure basket as well as the changes in the income of the household. Unlike most previous studies that only carry out first-order (or impact) measurement effects in which the household cannot react to trade-liberalization price changes, this paper takes into account households' behavioral responses to prices. ${ }^{2}$ Second, it traces the effects of trade liberalization on household earnings, taking into account household heterogeneity. Finally, this paper adds a geographic dimension to the analysis of price transmission, thereby recognizing that geographically disperse households will be affected differently by trade liberalization.

It is worth emphasizing that price transmission is especially important in low-income countries where local markets may be subjected to high transaction costs and are usually poorly integrated into the international economy. While several studies (e.g. Robertson (2000), Deaton (1997), Hanson (1997), and de Janvry, et al. (1991)) have emphasized this issue, the regional aspect of price transmission has usually been neglected (exceptions include Valdes (2002) and Larson (2002)). ${ }^{3}$

I start from a farm-household model in which the effects of trade liberalization on household welfare are transmitted through econometrically estimated adjustments in the prices of goods that affect household purchasing power while the econometrically estimated effects of trade liberalization on earnings affect household earnings. Estimation is carried out in three steps. First, I disentangle the effects of trade liberalization from the effects of other economic policies by adapting a pass-through approach to allow the transmission of border prices to domestic prices to vary by local markets. Second, movements in prices are translated to changes in wages through the estimation of an earnings equation. The third step aggregates the effects on purchasing power with those

\footnotetext{
2 The second-order effects for consumption are calculated using elasticity estimates in Nicita (2004).

${ }^{3}$ Those studies, indeed, find evidence of imperfect price transmission for factors and goods as a function of the level of development of rural markets.
} 
on earnings into the household's indirect utility function to obtain the trade liberalization effects on household welfare.

The remainder of the paper is organized as follows. Section 2 sets the stage by briefly describing the trade liberalization process in Mexico during the 1990s (especially in terms of changes in tariffs on the commodities used in this study), and the overall changes in poverty in Mexico during that period. Section 3 introduces the farmhousehold model and illustrates how it can be used to disentangle the effects of trade liberalization on prices and wages, and hence on households' welfare. The remainder of the paper deals with estimation and results. Section 4 presents the effects of tradeliberalization on prices and on wages. These estimates are used in section 5, which then computes the effects of trade liberalization on household welfare. Finally, section 6 summarizes the results and concludes. Several appendices on data and complementary estimates complete the paper.

To anticipate the main results, I find that Mexican trade liberalization during the 1990s has reduced the domestic prices of a number of agricultural and manufacturing products and increased the wage gap between skilled and unskilled. As a consequence, while all households gained by facing a less expensive consumption basket, households that were net suppliers of agricultural goods were hurt by lower agricultural income. Likewise, the downward pressure on unskilled wages hurt labor supplied by low-income households. ${ }^{4}$ Taken together, I find that even if all income groups have benefited by trade liberalization, those benefits were disproportionately distributed with richer urban households reaping most of them, hence increasing inequality. I also find strong regional effects. Mexican states closer to import (and export) markets (especially to the large United States market in the North) benefited most in term of increase in real income.

Moving beyond the Mexican results, arguably this case study speaks to the usefulness of the ex-post approach where the data are allowed to speak-up (which cannot be done in

\footnotetext{
${ }^{4}$ This is true assuming that household employment is fixed. An important effect of trade liberalization was to create additional jobs. Thus. wage differentials among sectors or increases in labor force participation would have raised household incomes.
} 
ex-ante simulations) and to the importance of capturing institutional details across markets (unlike ex-ante studies, trade liberalization's impact is modeled across different good and factor markets), and across regions. As to the basic framework outlined in the opening paragraph of this introduction, the details turn out to be important, at least in the case of Mexico.

\section{Mexico's Trade Liberalization and Households Welfare}

This chapter presents a brief over overview of Mexican trade liberalization, tariff structure, and the evolution of prices and poverty in the 1990s.

\subsection{Trade Liberalization}

Mexico's trade liberalization can be divided into four phases. Figure 2.1 shows the evolution of a standard openness measure with key events.

Mexico started opening its economy by 1985 with the elimination of a substantial part of import licenses. ${ }^{5}$ Nevertheless, this initial period of trade liberalization failed to increase imports for three main reasons. First, the goods that remained under control were also the ones experiencing fiercer competition from abroad. Second, the removal of licenses was compensated by an increase in tariff (from 23.5 percent to 28.5 percent). Finally, the nominal depreciation of the exchange rate was kept above the inflation rate making domestic goods cheaper. The second stage, the beginning of which is marked by the accession to the GATT in 1986, saw a sharp reduction in the tariff rates. ${ }^{6}$ In spite of this, some sectors remained largely protected with 20 percent of tariff lines still requiring import licensing. It is during this second phase that imports started increasing substantially, from about 17 billion USD in 1986 to about 42 billion in 1989.

\footnotetext{
${ }^{5}$ The coverage rate of licensing fell from 92 percent to 47 percent by the end of 1985 .

${ }^{6}$ The average tariff was reduced to about 13 percent by 1989 .
} 
A new stage in the Mexican liberalization process is identified from the start of NAFTA negotiations in 1990 to its implementation in 1994. In this period the import weighted average tariff further declined to reach about 9 percent by 1994. Nevertheless, trade restrictions were maintained in some sectors, mostly agricultural. This was a period of rapid economic growth (with a 4 percent GDP increase per year) registering a substantial increase in trade. Finally, the implementation of NAFTA signals the start of the fourth phase. NAFTA gradually reduced tariffs (from 9 percent to about 4 percent in 2000) and fostered deeper integration with the United States by deregulating key sectors, harmonizing standards and facilitating capital flows. It is in this fourth phase that trade flows increased dramatically, jumping from about 60 billion USD of imports in 1994 to about 170 billion in 2000 .

Under NAFTA, Mexico's tariff liberalization is to proceed gradually with liberalization occurring at different paces within different sectors. By 2000, about 80 percent of the tariff lines were free while the other 20 percent are to be removed gradually by 2008 . Still, key sectors of the Mexican economy are scheduled to be liberalized only in the very last period of NAFTA implementation. Those sectors, mainly dairy products, meat and to a lesser extent cereals, hardly experience any liberalization in the 1990s.

\subsection{Tariffs, Prices, and Wages in the $1990 \mathrm{~s}$.}

Since much of the effects of trade liberalization are on prices, it is opportune to illustrate the evolution of prices during the period of analysis. In examining the effect of trade liberalization on household welfare, this study analyzes 12 product aggregates: 8 agricultural and 4 manufacturing. These aggregates represent about 75 percent of the consumption basket of poor households. Poor households spend slightly more than 50 percent in food. Non-food manufacturing products represent about 25 percent of the consumption basket, while the rest consists of expenses in non-mapped products and services. ${ }^{7}$ Among the food products, the larger share is represented by processed food

\footnotetext{
${ }^{7}$ Non-mapped refers to expenditures which are not directly attributable to the goods of analysis. The most important being rent or imputed rent (about 20 percent).
} 
products (14 percent of the consumption basket), followed by cereals - mainly corn - (9 percent), meat products ( 8 percent) and dairy products ( 6 percent). Vegetables, oils and fats, fruits, and sugar characterize the remainder 13 percent. Table 2.1 reports the trends of real prices for the 12 products as observed from the analysis of the household surveys. ${ }^{8}$ Similarly, table 2.2 reports the average tariff for each good from 1989 to 2000.

Given the strong economic growth of the Mexican economy during the 1990s, it is not surprising that prices have declined substantially. All prices considered here with the exception of sugar decreased between 1989 and 2000. During this period, the decline of real prices has ranged from about 7 percent for cereals to about 40 percent for dairy products. ${ }^{9}$

With the exception of the sharp economic downturn of 1995, real wages increased steadily in Mexico during the 1990s. Moreover, the data reveals that skilled wages have been increasing at a much faster rate than unskilled wages. Most of the literature contends that the widening wage gap is one of the effects of trade liberalization (Revenga 1997). Figure 2.2 reports the log of real wages in Mexico for the border region and the rest of the country. With the exception of the sudden shift due to the economic downturn and devaluation of 1995 when both skilled and unskilled wages declined dramatically, unskilled wages were stagnant while skilled wages increased during the period of analysis. As a result, especially in the regions away from the northern border, the skilledunskilled wage gap has been increasing.

Hanson (1997) explains this outcome in the framework of the recent literature on geography and trade as the result of the fact that unskilled jobs were more protected to start with, and therefore trade liberalization hurt them disproportionately. Wages are observed to be substantially higher (both skilled and unskilled). This is compatible with the geography and trade literature which predicts that a reduction in transaction costs will affect the regional structure of wages, so that industries concentrate geographically, and

\footnotetext{
${ }^{8}$ To obtain real prices, nominal prices are deflated by the regional price indexes

${ }^{9}$ Similar decreases in the prices of agricultural goods have been observed by Yunez-Naude (2002) on the basis of government statistics.
} 
relative wages decrease with the increase of transport costs from the industrial center (Krugman, 1991, and Robertson, 2000).

\subsection{Poverty}

Despite Mexico's status as a middle-income country and a member of the OECD, poverty is widespread. According to the Comisión Económica para América Latina y el Caribe (CEPAL), ${ }^{10}$ the incidence of poverty remained stable around 40 percent during the $1990 \mathrm{~s}$. In 1989 poverty was estimated to be about 39 percent. ${ }^{11}$ The economic reform of the late 1980 s and early 1990s seems to have had an effect, as poverty was reduced to about 36 percent by 1994. The economic crisis of 1995 and the sharp devaluation of the peso then led to a sharp increase in poverty (43 percent in 1996). Finally, poverty levels were estimated to be around 40 percent in 1998 and around 39 percent in 2000. The incidence of poverty in Mexico varies widely by region. Northern states are on average the richer ones, with a substantially lower incidence of poverty than the states in the central regions (with the exception of the Mexico City area which registers a substantially lower level of poverty). Finally, the southernmost states are the ones that register the highest percentage of poor. Section 5 gives estimates of the effect of trade liberalization on each of the 32 states that compose the Mexican federation.

\section{Theoretical Framework}

This section presents the framework used to estimate the effect of trade liberalization on social welfare. It starts by describing the farm-household model used to explore the effect of price and factor movement on household welfare. Next, it develops a model to link the trade liberalization to changes in the prices of goods at a regional level. Finally, a third section links the price effect of trade liberalization on labor income.

\footnotetext{
${ }^{10}$ CEPAL - Panorama Social de América Latina, various years

11 Other studies have estimated a lower poverty incidence with poverty levels at about 10 percentage points below the ones reported by CEPAL (as in World Development Indicators, World Bank and in Lustig and Székely 1997). Since the analysis in this paper is based on real disposable income rather than poverty, the actual level of the poverty line is irrelevant for the purpose of this paper.
} 


\subsection{Trade Liberalization and Household Welfare}

In developing countries, most households are at the same time both consumers and producers of goods. In the case of Mexico more than half of the households receive at least one-third of their income from the sale of agricultural products. Therefore, in analyzing the effect of any policy on household's welfare it is important to recognize this dual role of the household. The farm household model fits this purpose (Singh, Squire and Strauss, 1986). In this model, the indirect utility function of the households can be written as: ${ }^{12}$

$$
u_{h}=V_{h}\left[y_{h}, P\right]=V_{h}\left[m_{h}+\pi_{h}, P\right]
$$

Household utility $u_{h}$ is expressed as a function of a vector of prices $P$ faced by the household and the household's income $y_{h}$. Total income is the sum of the income from farm activity $\pi_{h}$, and non-farm activity $m_{h}$, which in turn includes earned income (wages) and unearned incomes (gift, transfers and remittances).

While most of the literature bases the results on first-order effects, in this paper I augment the analysis to capture second-order effects on the expenditure side. The importance of taking into account household behavioral responses when analyzing social welfare has been emphasized by Nicita (2004). Therefore, in calculating welfare effect, I utilize the estimates of price and cross-price elasticities obtained in Nicita (2004).

Second-order effects can be calculated from the indirect utility function by differentiating equation 3.1 following a second-order Taylor series expansion approximation. This leads to:

\footnotetext{
${ }^{12}$ Social welfare is just the sum of all households' welfare.
} 


$$
\begin{aligned}
d u_{h} & =\sum_{g} \frac{\partial u_{h}}{\partial p_{\mathrm{g}}} d p_{\mathrm{g}}+\frac{\partial u_{h}}{\partial y_{h}} d y_{h}+\frac{1}{2}\left(\frac{\partial^{2} u_{h}}{\partial y_{h}^{2}} d y_{h}^{2}+\sum_{g} 2 \frac{\partial u_{h}^{2}}{\partial y_{h} \partial p_{g}} d y_{h} d p_{g}\right) \\
& +\frac{1}{2}\left(\sum_{g} \frac{\partial u^{2}}{\partial p_{g}} d p_{g}^{2}+\sum_{g} \sum_{k \neq g} 2 \frac{\partial u^{2}}{\partial p_{g} \partial p_{k \neq g}} d p_{g} d p_{k \neq g}\right)
\end{aligned}
$$

This expression can be simplified by assuming the marginal utility of income $\partial u_{h} / \partial y_{h}=1$, and by applying Roy's identity, ( $\left.\partial u_{h} / \partial p_{g} / \partial u_{h} / \partial y_{h}=-c_{g}\right)$. Hence, equation 3.2 can be written as:

$d u_{h}=d y_{h}-\sum_{g} c_{g}-\sum_{g}\left(\frac{\partial u_{h}}{\partial y_{h}} c_{g} d p_{g}\right)-\frac{1}{2}\left(\sum_{g} \frac{\partial c_{g}}{\partial p_{g}} d p_{g}+\sum_{g} \sum_{k} 2 \frac{\partial c_{g}}{\partial p_{g} \partial p_{k \neq g}} d p_{g} d p_{k \neq g}\right)$

where $d u_{h}$ is the approximation of the monetary value of the change in indirect utility for households $h, c_{g}$ is the consumption of good $\mathrm{g}$ and $d p_{g}$ is the change in the price of good g.

Income of household $h$ is given by the sum of labor income and profits associated with the household's own production of a particular good.

$$
y_{h}=\underbrace{w \ell_{h}}_{\text {labor income }}+\underbrace{\sum_{g} \pi_{h g}}_{\text {profits }}
$$

where $\mathrm{w}$ is the prevailing wage rate, $\ell_{h}$ is the (net) amount of labor sold in the market by household $h$ and $\pi_{h, g}$ are profits obtained from directly selling good $g$ in the market.

Further, assume that households choose optimally the amount of labor to sell in the labor market and the amount to produce in their own business. Then, the effect of prices and wages on profits can be obtained by differentiating (3.4) using Hotelling's Lemma $\left(d \pi_{h} / d p_{g}=x_{h g}\right)$, which yields: 


$$
d y_{h}=d w \ell_{h}+\sum_{g} x_{h g} d p_{g}
$$

where $x_{h g}$ is the quantity of good $g$ sold on the market by household h. Substitute equation (3.5) into (3.3), divide everywhere by income of household $h$ assuming that income equals expenditure, and rearrange terms to obtain the percentage change in welfare:

$$
\begin{aligned}
\frac{d u_{h}}{y_{h}}=\underbrace{\theta_{h}^{\ell} d w_{h}}_{\text {labor }}+\underbrace{\sum_{g} \theta_{h g}^{x} d p_{g h}}_{\text {agric.income }}-\underbrace{\sum_{g} \theta_{h g}^{c} d p_{g h}}_{\text {consumption }}-\underbrace{\sum_{g} \eta_{h g} \theta_{h g}^{c} d p_{g h}}_{\text {income effect }} \\
\\
-\frac{1}{2}(\underbrace{\sum_{g} \varepsilon_{h g} \theta_{h g}^{c} d p_{h g}^{2}}_{\text {price effect }}+\underbrace{\sum_{g} \sum_{k \neq g} 2 \varepsilon_{h g k} \theta_{h g}^{c} d p_{g h} d p_{k h}}_{\text {cross price effect }})
\end{aligned}
$$

where $\eta_{h g}$ is the income demand elasticity, $\varepsilon_{h g}$ is the price elasticity of demand and $\varepsilon_{h k g}$ is the cross price elasticity of good $g$ to good k. And where $\theta_{h g}^{c}=p_{g h} c_{h g} / y_{h}$ is the share of income spent on good $g$ by household $h ; \theta_{\mathrm{h}}^{\ell}=\mathrm{w} \ell_{\mathrm{h}} / \mathrm{y}_{\mathrm{h}}$ is the share of income obtained in the labor market by household $h$ and $\theta_{h g}^{x}=p_{g h} x_{g} / y_{h}$ is the share of income of household $h$ obtained by selling good $g$ in the market at price $p$. Finally, changes in wages $\left(d w_{h}\right)$, prices $\left(d p_{g h}\right)$ and income $\left(d y_{h}\right)$ are expressed in percentage terms.

Equation (3.6) suggests that a change in the price of good $g$ favors or harms the household to an extent given by the "net exposure" of its budget to that particular good. Equation (3.6) is a measure of the percentage change in money metric utility, whereby the indifference curves of individual preference ordering are labeled by the amount of money needed to reach them at some fixed level of prices, which is commonly approximated by real income (Deaton and Muellbauer, 1980). In order to express the change in welfare in monetary units, one simply needs to multiply the expression in equation (3.6) by household income. 
To estimate equation (3.6), one would need first to calculate the percentage change in prices $\left(d p_{g h}\right)$ and wages $\left(d w_{h}\right)$, and the income $\left(\eta_{h g}\right)$, price $\left(\varepsilon_{h g}\right)$, and cross-price $\left(\varepsilon_{h k g}\right)$ elasticities. Regarding elasticities, the measurement of the slopes of the demand function for Mexican households has been done in Nicita (2004), which obtains own and crossprice elasticities of demand and income elasticities for 10 agricultural products for five income categories of households. Regarding prices and wages, the strategy to retrieve those estimates is explained in the next two sections.

\subsection{Trade Liberalization and the Extent of Pass-through}

The model presented in section 3.1 states that the impact of trade policies on household welfare operates though movement in the prices of goods and factors faced by the household. Moreover, besides the structure of income and consumption of each household, market characteristics are important in determining the extent to which trade reforms are able to influence domestic prices and hence households' welfare. To influence households, trade policies operate through markets that must be able to transmit the effects of trade reforms. Market imperfections, and more generally trade costs, may isolate households partially or even completely from the effect of trade related policies (Janvry, Fafchamps and Sadoulet 1991, Taylor and Adelman 1996).

I now outline a pass-through model that quantifies the extent to which movements in the prices observed during 1989-2000 can be directly imputed to trade liberalization. This model isolates the effects of trade policy changes that one needs for the estimation of equation (3.6)

To capture the effect of trade liberalization on prices, this paper adopts a model based on the tariff pass-through literature (Feenstra 1989), according to which the change in the domestic price of an imported good is determined by the change in the tariff rate multiplied by the price of the imported good and adjusted by changes in the exporter 
markup. ${ }^{13}$ Because the level of development of domestic markets matter, the model in this paper is constructed to capture trade costs so as to take into account the extent to which local markets are receptive to movements in the prices at the border.

In this setup the domestic price for imported good $g$ in time $t$ in region $r\left(P_{g t r}\right)$ is a function of the international price $\left(P X_{g t}{ }^{*}\right)$, the exchange rate $\left(e_{t}\right)$, the tariff $\left(\tau_{g t}\right)$ and trade costs $\left(T C_{g t r}\right)$

$$
P_{g t r}=e_{t} P X_{g t}^{*}\left(1+\tau_{g t}\right) T C_{g t r}=e_{t}\left(\phi_{g t r} C P_{g t}^{*}\right)\left(1+\tau_{g t}\right) T C_{g t r}
$$

where the asterisks denote variables expressed in foreign currency and where the international price is assumed to be equal to the cost to produce the $\operatorname{good}\left(\mathrm{CP}_{\mathrm{gt}}{ }^{*}\right)$ multiplied by a markup $\phi_{g t r}=1+\lambda_{g t r}$, where $\lambda_{g t r}$ is the profit margin.

To estimate how much of the movement in the border price is passed-through to the domestic prices and how much is internalized by changes in the unobserved markup, this paper applies the following approach. Assume that the profit margin depends on competitive pressures in the domestic market, which, is proxied by the ratio between the price of import competing goods in region $r\left(P D_{g t r}\right)$ and export production cost to produce and sell the good in the region. The profit markup is thus model:

$$
\phi_{g t r}=\left(\frac{P D_{g t r}}{C P_{g t}^{*} e_{t}\left(1+\tau_{g t}\right) T C_{g t r}}\right)^{\alpha}, \text { and } 0 \leq \alpha \leq 1
$$

where $\alpha$ is a parameter that can be though as the level of competition in the domestic market. Substituting (3.8) in (3.7) and expressing production costs in domestic currency gives: ${ }^{14}$

\footnotetext{
${ }^{13}$ Goldberg and Knetter (1997) offer and exhaustive review of the pass-through literature.

${ }^{14}$ To see the reasoning behind, setting in equation $3.9 \alpha=1$ (no pass-through), domestic prices are equal to the price of import competing goods. Therefore foreign product cannot be profitably sold in the domestic market.
} 


$$
P_{g t r}=\left(\frac{P D_{g t r}}{C P_{g t}\left(1+\tau_{g t}\right) T C_{g t r}}\right)^{\alpha} C P_{g t}\left(1+\tau_{g t}\right) T C_{r}
$$

finally taking logarithms

$$
\ln P_{g t r}=\alpha \ln P D_{g t r}+(1-\alpha) \ln C P_{g t}+(1-\alpha) \ln \left(1+\tau_{g t}\right)+(1-\alpha) \ln T C_{g t r}
$$

where $1-\alpha$ represents the pass-through.

The literature on pass-through captures the arguments of equation (3.10) through a unrestricted form for which the coefficients $1-\alpha$ can differ both in sign and in magnitude (e.g. Goldberg and Knetter 1997 and Campa and Goldberg 2002). Thus, equation (3.10) becomes:

$$
\ln P_{g t r}=\beta_{0}+\beta_{1} \ln X_{g t}+\beta_{2} \ln Z_{g t r}+\beta_{3} \ln T C_{g t r}+\gamma \ln \left(1+\tau_{g t}\right)+\varepsilon_{g t r}
$$

where $X_{g t}$ is the primary control variable which proxies for $C P_{g t}$ ( $X_{g t}$ is the international price of good $g$ expressed in domestic currency), while $Z_{g t r}$ proxies the price of import competing goods $P D_{g t r}\left(Z_{g t r}\right.$ is a vector of control variables that includes local supply and regional income), and $\varepsilon_{g t r}$ is an i.i.d. error term. In this setup, the parameter $\gamma=1-\alpha$ is the pass-through elasticity. The pass-through is defined as the percentage change in the domestic price resulting from a one percent change in the tariff rate between the importing and exporting countries. In the extreme case when $\alpha=0$ the exchange rate pass-through is complete and exporting firm do not face competition in the importing markets (therefore enabling it to pass-through the full extent of the change in tariff into the priced of the good paid by consumers). On the other hand when $\alpha=1$ the pass-through is zero and exporting firms must set their price equal to competitors' price in the importing market. 
As a proxy for trade cost in equation (3.11) this paper utilizes a variable $(d)$ constructed by the distance from the main port of entry of the product. Since about 80 percent of Mexico's imports originate from the United States, the trade cost variable is constructed as the shortest driving distance (in thousand of kilometers) from each of the state's capital to the United States border (Tijuana, Ciudad Juarez and Nuevo Laredo). ${ }^{15}$ With the use of distance, the assumption is that the trade costs are constant across the time period of the analysis.

Because a primary concern is to measure the effect of tariff liberalization on domestic prices at the regional level, the empirical specification includes an interaction term between the distance and the tariff rate, so as to isolate empirically the regional effect of tariff movements in the pass-through. Therefore, the estimating equation is given by:

$\ln P_{r g t}=\beta_{0}+\beta_{1} \ln X_{g t}+\beta_{2} \ln Z_{g t r}+\beta_{3} d_{r}+\gamma \ln \left(1+\tau_{t g}\right)+\gamma_{1} \ln \left\{\left(1+\tau_{t g}\right) d_{r}\right\}+\varepsilon_{r g t}$

The coefficients of interest are: $\gamma$ that represents the tariff pass-through elasticity (i.e. the percentage increase in the import prices for a one percent increase in the tariff), and $\gamma_{1}$ that is its adjustment for each region. The pass-through is "full" or "complete" if $\gamma=1$ and the pass-through is "incomplete" if $\gamma<1$. Similarly, the effect of the pass-through will be identical in all regions if $\gamma_{1}=0$. On the other hand, if regional prices vary as a consequence of movement in the tariff, then $\gamma_{1} \neq 0 .{ }^{16}$

The econometric estimation of equation (3.12) follows Deaton (1985) and combines a time series of cross-sectional data set into a pseudo panel. ${ }^{17}$ The data consist in domestic

\footnotetext{
${ }^{15}$ About 80 percent of Mexican imports from US is through the northern border.

${ }^{16}$ Furthermore, since the United States is the only country that borders Mexico from the north, a positive and significant coefficient $\gamma_{1}$ may be interpreted as the fact that pass-through elasticities are higher for southern regions. Indeed this is likely in the case when a product is predominantly imported from other Latin American countries.

${ }^{17}$ From a time series of cross section surveys, synthetic cohorts are defined as groups with fixed membership, whose individuals (or households) can be identified as they show up in the surveys. For this reason, groups are defined according to some time invariant variables. Means within each cohort are
} 
prices for 32 regions and six time periods. Average prices for each region are arranged into a panel data set and the estimation is performed for each of the goods $g$. This crosssectional time-series model is estimated using generalized least squares with random effect. $^{18}$

Finally, to obtain the percentage change in prices $d p_{g}$ necessary to apply the model of section 3.1, one needs to calculate:

$$
d p=\frac{\tilde{P}_{\text {tar } 89}-\tilde{P}_{\text {tar } 2000}}{\tilde{P}_{\text {tar } 2000}}
$$

where $\tilde{P}_{\text {tar } 2000}$ represents the price estimates for the year 2000 and $\tilde{P}_{\text {tar } 89}$ refers to the prices estimated from equation (3.12) calculated with the tariff of 1989. The subscripts for household and goods are omitted for the sake of simplicity. The discussion on the results of the pass-through elasticities is presented in section 4.1.

\subsection{Trade Liberalization and Labor Income}

It is well known that if trade liberalization passes through on domestic prices, the factor market will be in disequilibrium, thereby resulting in factor income adjustments. Moving beyond the prediction of the Stolper-Samuelson theorem to actual changes, as Topel (1986) first suggested, worker heterogeneity is important for labor earnings. Therefore, besides the movement of prices, data on wages that can be differentiated by geographic region, demographic groups, and individual characteristics would be crucial for a successful examination of how economic shocks, such as trade reforms, are transmitted across different households.

calculated and followed for each temporal unit under examination: this cohort aggregation is defined as a pseudo panel.

${ }^{18}$ Hausman specification test could not reject the hypothesis that the random effect model is correctly specified. The stationarity of the time series is checked by using a Hadri LM test (Hadri, 2000). The results do not reject the hypothesis that all the series in the panel are stationary 
This suggests using a model that, in estimating earnings, takes into account both the movement in good prices and worker characteristics. In doing so, I follow the approach of Porto (2003), with minor modifications. ${ }^{19}$

The earning equation for each individual can be written as:

$$
W_{i j t}=W_{i j t}\left(P_{g t}, H_{j t}, Z_{i t}\right)
$$

where $W_{i j t}$ is the wage of individual $i$ in household $j$ at time $t, P_{g t}$ is a vector of prices for goods $g$ in time $t, H_{j t}$ is a vector of household characteristics and $Z_{i t}$ is a vector of individual characteristics. In this setup, household survey data is well suited for the estimation because it collects information on both prices and wages.

To derive the wage price elasticities, my estimation strategy follows a varying coefficient model (Hsiao 1986) where the variability of the coefficient is given by regional and time differences. The estimating earning equation, which incorporates the role of product prices and worker characteristics, is:

$$
\ln w_{i j t}=\sum_{g, r, s} \theta^{r} \theta^{s} \ln p_{i j}^{g, r} \beta_{i j}^{g, r, s}+Z_{i t} \gamma+H_{j t} \delta+\varepsilon_{i j t}
$$

where $w_{i j t}$ is the observed wage of individual $i$ in household $j$ in time $t, p_{i j}^{g, r}$ is the price of good $g$ faced by the individual in region $r, Z_{i}$ is a vector of individual characteristics (age, gender, household head status, and type of employment), $H_{j}$ represents a vector of household characteristics (average expenditure by region, and the number of workers, skilled or unskilled, that the household faces in its region of residence). Finally, $\theta^{r}$ and

\footnotetext{
${ }^{19}$ The difference resides in how to retrieve the coefficient of interest. In the estimation, Porto (2003) interacts prices with regional and schooling dummies but not with both simultaneously.
} 
$\theta^{s}$ represent dummy variables for region of residence and worker skill ${ }^{20}$, and $\varepsilon_{i j t}$ is an error term. ${ }^{21}$ In short, I regress individual wages on the prices of goods interacted with regional and schooling dummies, plus individual controls.

Within this setup, wage responses to prices (the $\beta_{i j}^{g, r, s}$ ) are limited to vary only across regions and between skilled and unskilled workers. Hence, the varying coefficients of the price regressors depend on the region of residence of the household and the level of education of the individual. The estimation produces a set of $r \times s$ coefficients $\beta_{i j}^{g, r, s}$ for each group of goods $g$, which will capture the effect of a particular price on a type of wage in a determined region.

The estimation at the most disaggregated level with two types of wages would have a very large number of price regressors (to be exact, 768), many of which would be highly collinear and therefore increase the confidence intervals of the coefficients, making interpretation quite difficult. Multicollinearity, along with the advantage derived from a more linear exposition of the results, drives me to estimate the model with the prices of all the agricultural products aggregated into one single category. ${ }^{22}$ This aggregation implies that I assume that prices of different agricultural products affect wages in similar ways. This would be the case if the production function of different agricultural goods is identical. By contrast, wage price elasticities are estimated for each of the four manufacturing sectors, where labor mobility across sectors is lower, production technologies are different, and where factor endowments and price movement are likely to be less homogeneous.

\footnotetext{
${ }^{20}$ Workers are differentiated in skilled and unskilled according to their level of education. Workers with 9 or more years of education or that have completed industry specific training are considered skilled.

${ }^{21}$ Idiosyncratic components, such as exogenous time shocks, are controlled for by taking a fixed effect approach in estimating equation (3.15). Hence, the error term has the form: $\varepsilon_{i j t}=\omega_{t}+\eta_{i j t}$, where $\omega_{t}$ is the fixed effect for year $\mathrm{t}$ and $\eta_{i j t}$ is an i.i.d. term with mean zero and variance $\sigma$.

22 The aggregation is weighted by the household's budget share of each product in the agriculture aggregate.
} 
Likewise, to reduce the number of geographic entities, the 32 states are aggregated into 5 regions similarly as in Hanson (1997). ${ }^{23}$ Optimally, those five regions aggregate states with analogous regional economies and integrated labor markets. This assumes that labor markets clear at this more aggregated regional level instead of by state. Moreover, workers are assumed to supply different types of labor services depending on the educational level they have attained and the region where they reside. Arguably, these assumptions are reasonable in the case of a developing country such as Mexico. ${ }^{24}$

To summarize, the model is estimated with 5 goods (agriculture, food products, textiles and apparel, household equipment, and other manufacturing), 5 regions (US border, north, center, Mexico City area, and south), and 2 levels of wages (skilled and unskilled). To better capture the effect of prices on wages, the data from the six household surveys are stacked together, therefore compensating for the fact that prices may not vary significantly within one single survey to allow the estimation of such price-wage elasticities. Finally, to reduce the effects of measurement error, observations with the lowest or highest 0.25 percent of wage values for each year are dropped.

The estimation equation also includes several control variables. Specifically, I include the age and gender of the worker, a dummy variable that control for his or her status as household head, and a categorical variable to capture wage premiums for skilled individuals that have completed secondary education or college. Furthermore, two dummies control for job characteristics (permanent or temporary position and employment in agricultural work). Year dummy variables are included in the regression to control for fixed year effects. Finally, region-specific issues are captured by the inclusion of a variable for average regional expenditure (which controls for the varying cost of living) and a variable capturing the regional labor endowments (which controls for the supply of skilled/unskilled labor in the region). The estimation is run for all individuals reporting salaried wages between 18 and 65 years of age. ${ }^{25}$ The estimation

\footnotetext{
${ }^{23}$ Figure A.1 in the appendix illustrates the 32 Mexican states and their geographical aggregation.

${ }^{24}$ Further details on the aggregations are discussed in the data appendix.

${ }^{25}$ To limit the effect of measurement error, the estimation is restricted only to employed individuals. Self employed individuals reporting imputed wages are not included in the estimating sample.
} 
follows a standard OLS procedure with standard errors corrected for heteroskedasticity and survey design. Finally to obtain the percentage change in wages $\left(d w_{h}\right)$ necessary in the estimation of equation (3.6) ones needs to calculate:

$$
d w_{h}=\sum_{g} \beta_{g} d p_{g h}
$$

where $\beta_{g}$ is the price-wage elasticities for good $g$ from equation (3.15), and $d p_{g h}$ is the percentage change in price faced by the household from equation (3.13). For the sake of simplicity, the subscripts for region, time and skilled/unskilled wages are omitted. The results on the price-wage elasticities are presented in section 4.2

\section{Results: Pass-through and Wage-price Elasticities}

The results are discussed in the following order: first the pass-through elasticities obtained by the estimation of equation 3.12, then the price-wage elasticities estimated by equation 3.15, and finally the results on household welfare from equation 3.6.

\subsection{Results: Pass-through Price Elasticities}

In the model outlined in section 3.2, the pass-through effects are captured by the coefficients of the tariff and tariff-distance variables. In principle, trade theory suggests a positive sign on the pass-through coefficient $\gamma$ and, since most Mexican imports originate from the United States, a negative sign on the interacted term $\gamma_{1}$ (pass-through distance). Within this setup, if any of the products enter the country mainly from the southern border, then a positive coefficient in the interaction term is expected. Table 4.1 reports the results for the 12 product aggregates. In most cases, the coefficients of interest have the expected sign and are significant at the 10 percent level or better. Following is an explanation of the results from the estimation of equation 3.12 for the 8 agricultural products and then for the 4 manufacturing products. 
Starting with agricultural product, for cereals (represented mostly by maize), the results indicate a pass-through coefficient at the border of about 32 percent. Give the fact that the coefficient $\gamma_{1}$ is -0.17 , the change in tariffs fails to produce any effect for regions that are farther than 1900 kilometers from the northern border. ${ }^{26}$ Considering that 98 percent of the imported cereals originate in the United States and that imports account for about 20 percent of consumption, the low pass-through effect for cereals is probably also driven by the fact that transportation costs are high and local production quickly becomes more profitable. ${ }^{27}$ Pass-through effects are not observed in the case of dairy products the reason being that the dairy sector was largely exempted from tariff liberalization and the NAFTA tariff schedule during the 1990s. As with dairy products, pass-through effects are not observed for meat and pulses. In those cases the coefficients have an unexpected sign. Variety and quality issues likely influence these markets. For pulses, a likely explanation resides in the fact that they are mostly produced for local consumption, hence, the local markets probably play a significant role in setting the prices, hindering the transmission of border prices to regional markets. ${ }^{28}$ In the case of meat, imports account for about 20 percent of consumption. Nevertheless, the meat sector is still largely protected (the tariff moved from about 10 percent in 1989 to about 8.5 percent in 2000).

Significant pass-through coefficients are observed for fruits and vegetables (respectively at 22 and 14 percent). While there is no significant difference across regions in the case of vegetables, the pass-through coefficient for fruit is higher in the southern regions. This may be due to the fact that, contrary to the case of cereals, imports of fruit and vegetables mostly originate in other central American countries rather than in the United States. In the case of oils and fats, the pass-through elasticity is about 22 percent and there is also a positive and significant coefficient in the interaction term, meaning that prices are more responsive to the tariff in regions that are far away from the northern border. This is explained by the fact that Mexico imports less than half of oils and fats from the United

\footnotetext{
${ }^{26}$ That is given by $-\left(\gamma / \gamma_{1}\right) 1000$. In the case of cereals is- $(0.326 / 0.171)^{*} 1000$

${ }^{27}$ Quality of cereals, in particular of corn is a very important issue in Mexico. This makes imports an imperfect substitute for local production.

${ }^{28}$ Only about 2 percent of pulses are imported. Also, as argued by Yunez-Naude (2002), Mexican consumers tend to largely favor locally produced beans because of freshness and quality. This makes domestic beans and imported beans two different products which prices may be uncorrelated.
} 
States, while the rest enters the domestic markets from south. For sugar the pass-through coefficient is estimated to be approximately 26 percent and given the fact that the price of sugar is subject to partial government control, this elasticity does not vary much across regions.

I discuss next the results for the four manufacturing product aggregates. In this case, all the coefficients of interest have the expected sign and are significantly different from zero at the 1 percent level. Since imports of manufacturing products cover more than one quarter of internal consumption and more than 75 percent of imports originated from the United States, one would expect a closer relationship between domestic and international prices. Furthermore, the manufacturing sector has experienced a much more important liberalization than the agricultural sector, which it is expected to produce a more complete prices pass-through.

In the case of manufactured food products there is full pass-through for regions at the border with the United States. This effect gradually fades away for regions farther from the border at the rate of about 12 percent every thousand kilometers. Considering that for the most remote regions the distance from the border is about 4,000 kilometers, the effect of the tariff pass-through for the most southern states is about 50 percent. Results also indicate a high pass-through in the case of household equipment, (76 percent with a decline of about 11 percent per thousand of kilometers). Slightly lower is the passthrough effect in the case of textiles and apparel products (about 54 percent with a decrease of about 10 percent every thousand kilometers from the United States border). Finally, the effect for other manufactured goods, resulted in a pass-through of about 67 percent. The rate of decline as a function of distance from the United States border is about 11 percent per thousand kilometers.

In summary, the results indicate that changes in tariff have different effects for different products. Manufacturing products are in general more responsive to changes in tariffs, while the domestic prices of agricultural products are influenced to a lesser extent, if at all, to changes in tariffs and exchange rates. The rationale is likely explained by the fact 
that agricultural products are still very much protected through tariff and non-tariff barriers and for quality issues derived for Mexican taste for own corn. Furthermore, agricultural products usually face more competition from internal markets (especially in rural areas) and are characterized by higher transport costs. From this point of view, the change in border prices is more likely to be absorbed by changes in the profit margin of exporters rather than result in an adjustment in domestic prices. For rural areas poorly connected with the international markets, domestic supply is likely to set the price of certain agricultural products regardless of border measures. This is especially the case when the imports represent only a small part of domestic consumption, as with cereals, legumes and meat products in Mexico.

Other studies focused on the magnitude of the pass-through results have observed passthrough coefficients of around 60 percent for manufacturing products (Goldberg and Knetter 1997) and Yang (1997), which obtains similar results using United States manufacturing data. ${ }^{29}$ The results of those studies are very similar to the ones of this paper with respect to the manufacturing sector. Pass-through coefficients for agricultural products have rarely been estimated, and in most cases have turned to be much lower than those for manufacturing products (Campa and Goldberg 2002). However, while most of the literature has explored only country average effect of pass-through, this paper is, to my knowledge, the first to explore the extent to which pass-through rates are different across regions. The findings indicate that for manufacturing products, passthrough coefficients decrease at a rate of about 10 percent per thousand kilometers from the main port of entry. Meanwhile, pass-through effects are more heterogeneous for agricultural products, with that of cereals decreasing at a rate of about 12 percent per thousand kilometers. The effect seems to be more heterogeneous for other agricultural products probably due to the more diverse origins of the imports. Further results on the observed change in prices and factor returns due to trade liberalization are presented in appendix B.

\subsection{Results: Price-wage Elasticities}

${ }^{29}$ Yang finds that the rate of pass-through varies substantially both across and within industries. 
This section illustrates the extent to which movement in the price of goods have influenced the return of labor as estimated from the model in section 3.3. As suggested, in section 3.3, the Stolper-Samuelson theorem gives full results only in a $2 \times 2$ model. A $n \times m$ case in infinitely more complex and one can only infer correlations between product prices and factor returns. In theory, one would expect to observe positive relationships between prices and factor returns in the case that the product for which there is a change is relatively intensive in the production structure of the region. (e.g. if the price of apparel is increasing and a region is intensive in this sector then I would expect an increase in the wage in that region). Also, ones would expect that products which imbed a higher factor intensity of a particular type of labor, would produce a larger effect on the return for that particular type of labor. (e.g. if the agricultural sector is intensive in unskilled labor, then I would expect that agricultural prices affect unskilled labor in a larger extent to skilled labor). Table 4.2 reports the estimated price-wage elasticities.

To start with the control variables, all coefficient estimates resulted of the expected sign with a level of significance of 1 percent or better. In particular, the coefficient on the age variable indicates that there is an average premium of about 0.9 percent in the wage for each additional year of age. Individuals that completed superior education and college are demonstrated to have wages respectively 19 percent and 38 percent higher than other skilled individuals. Gender is also a determinant of wages: ceteris paribus, men earn about 12 percent more than women. ${ }^{30}$ The other control variables indicate that on average agriculture workers earn about 71 percent less than workers employed elsewhere, permanent workers earn about 36 percent more than workers hired with a temporary contract, and household heads earn on average about 52 percent more than other members of the family. Finally, regional labor supply and average expenditures also enter significantly and with the expected sign in the estimation.

\footnotetext{
${ }^{30}$ Given the log-linear form of the estimation, the percentage change in the dependent variable due to the dummy variable is $\left(e^{\beta}-1\right)$
} 
Of greater interest are the estimates for the 50 price-wage elasticities: 10 responses for each of the prices of the five product aggregates, each of which is estimated for two different skill levels. In the results, it is expected that prices of products that have a dominant position in the overall economy of the region would positively or negatively affect wages depending on the factor intensity in the industry. I now turn to briefly illustrate the results for the five different product aggregates.

For the border and northern regions the prices of food products affect wages significantly and negatively. ${ }^{31}$ The differences between the responses of skilled and unskilled wages show a substantial homogeneity of the results, with skilled wages slightly less responsive to changes in prices (62 percent of price unskilled-wage elasticity versus 48 percent of price skilled-wage elasticity). Since trade liberalization has produced a decline in the real price of food products (and the price-wage elasticity is negative), this has had a positive impact on all wages, both of skilled and unskilled individuals.

For household equipment, I find a negative association between prices and skilled wages, while, with the exception of the case of the central region, unskilled wages are unresponsive. Regional differences are present, with the wages in the Mexico City area being more responsive (price-wage elasticity of 92 percent) than the northern region (58 percent), the central region (33 percent), and the border region (29 percent). Since trade liberalization has produced a decline in the price of household equipment the result on wages is positive. Furthermore, since the price effect is almost exclusively relegated to skilled wages, trade liberalization has increased the gap between the remuneration of skilled and unskilled jobs.

Results for textile and apparel products indicate a positive relationship between prices and both skilled and unskilled wages. The relationship between prices and wages turned significant in the case of regions where the textile industry is particularly important: the

\footnotetext{
${ }^{31}$ Stopler-Samuelson theorem suggests that a factor of production could be negatively correlated with the prices of a particular product if the product is not intensive in that factor. Another reason for negative correlation can be found in the production function, i.e. in the distribution of returns to different factors due to change in the prices of each of the factor of production or in the production technology.
} 
border region and the Mexico City area. On average, unskilled wages seem to be more responsive than skilled wages to the change of prices in textiles and apparel products, hence suggesting that textiles and apparel are intensive in unskilled labor in Mexico. In the case of the border region, the price-wage elasticity is measured at 53 percent for unskilled wages and 41 percent for skilled wages. In the Mexico City area the elasticity for unskilled wage is 79 percent, while for skilled wages it is about 53 percent. Trade liberalization has produced a decline in the price of textile and apparel products and therefore the effect on wages is negative.

Finally, in the case of other manufactured goods, the price-wage elasticities turned out to be significant only in the border region. In this region the response to changes in price is about 46 percent for unskilled wages and 35 percent for skilled wages. Since trade liberalization has resulted in an overall decline in the price of other manufactured goods, this caused downward pressured on the wages in the border region.

In the case of changes in the prices of agricultural products, wages of unskilled individuals are positively correlated or unresponsive to changes in the prices of agricultural products. The wage response is significant in the case of the most agricultural regions, especially the northern and the southern regions. The price-wage elasticity is about 71 percent for unskilled workers in the northern region and about 118 percent for unskilled workers in the southern region. ${ }^{32}$ Skilled wages are affected in the northern region but negatively. Because trade liberalization has produced a decline in the prices of agricultural products, unskilled workers in the southern and northern agricultural regions have suffered, which has contributed to the widening gap in the remunerations between skilled and unskilled individuals.

To sum up, the northern regions and those closer to the United States border have experienced the largest increase in wages. Meanwhile, wages in the southern regions have declined. This result is consistent with the results of Hanson (1996), which finds

\footnotetext{
${ }^{32}$ The fact that the increase in the wages is higher than the increase in the price is not a reason of concern. Leamer (1996), for example, has found wage responses up to fourfold the increase in price.
} 
that regional wages are influenced by access to foreign markets. The results can also be summarized geographically. While in the most manufacturing-intensive regions close to the United States border and in the Mexico City area wages are largely affected by prices of manufacturing products, in more rural regions, especially in the south but also in the northern agricultural regions, wages are affected by the prices of agricultural products. Regarding differences in skilled and unskilled earnings, in most cases both types of wages have moved in the same direction as a result of changes in price. Skilled wages were found to be significantly more responsive than unskilled wages in the case of a skilled-labor intensive industry such as household equipment. The opposite is observed in the case of a change of prices in textile and apparel products. As trade theory predicts that consequent to trade liberalization production will relocate to the sector that uses the relatively abundant factor (and unskilled labor in Mexico is arguably more abundant than skilled labor), then it is expected an increase in the demand for unskilled workers and, as predicted by the Stopler-Samuelson theory, the relative unskilled wage is set to increase. Nevertheless, as in most other studies for Mexico (Hanson and Harrison 1999, Feenstra and Hanson 1997, Revenga 1997), I do not find overall evidence of this effect. One reason is to be found in the fact that before trade liberalization, Mexico was disproportionately protecting unskilled intensive industries. Since the reduction in trade barriers was most dramatic for those industries, unskilled labor was affected disproportionately.

\section{Estimates of Trade Liberalization on Household Welfare}

Recall that equation 3.6 gives a measure of households income change to a change in prices therefore providing an estimate of the effect of Mexican trade liberalization on household's welfare. To summarize this information, I aggregate the households into groups according to their income level and geographic region. Welfare measures are presented as averages within each group. Taking into account the different types of labor and the fact that estimates are by region, equation (3.6) is rewritten as: 


$$
\begin{aligned}
& \frac{d u_{h}}{y_{h}}=\sum_{s, u} \theta_{h}^{s, u} d w_{r}^{u, s}+\sum_{g} \theta_{h g}^{x} d p_{g r}-\sum_{g} \theta_{h g}^{c} d p_{g r}-\sum_{g} \eta_{h g} \theta_{h g}^{c} d y_{h} \\
& -\frac{1}{2}\left(\sum_{g} \varepsilon_{g} \theta_{h g}^{c} d p_{g r}^{2}+\sum_{g} \sum_{k \neq g} 2 \varepsilon_{g k} \theta_{h g}^{c} d p_{g r} d p_{k r}\right)
\end{aligned}
$$

where $\theta_{h}^{s, u}$ denotes the share of income from skilled or unskilled labor, while $\theta_{h g}^{x}$ is the income share from the sale of good $g$ and $\theta_{h g}^{c}$ denotes budget shares for good g. The parameters $d w_{r}^{s, u}$ are retrieved from the estimation of equation (3.15) and discussed in section 4.2. The parameter $d p_{g r}$ are retrieved from equation (3.13) and discussed in section 4.1. While, as mentioned before, the income $\left(\eta_{g}\right)$, price $\left(\varepsilon_{g}\right)$, and cross-price $\left(\varepsilon_{g k}\right)$ elasticities estimates are from Nicita (2004).

The distributional effect illustrated in figure 5.1 suggests that all income groups benefited from trade liberalization. At the same time, the richer the household (to the right in the figure), the more its disposable income increased. While poorest households have gained about 2 percent from trade liberalization, for the richest households the gains are more substantial, about 6 percent. Note that according to equation (5.2), the household's utility ultimately depends on the level of expenditure needed to purchase a determinate basket of goods, on the value of its agricultural output, and on the wage of its labor. Hence figure 5.2 explores how each group of households fare with respect to these components.

Figures 5.2a and 5.2b illustrate respectively the overall consumption and income distributional effects. Figure 5.2c further divides the effect of change in welfare due to consumption into changes in manufacturing and agricultural prices. Finally, figure 5.2d illustrates the extent to which the change in income is due to changes in the value of the agricultural production and changes in the remuneration of the wages received by household members. From these figures it appears that the only way in which poor households gain from trade liberalization is from the fact that goods in the consumption baskets, especially manufacturing products, are less expensive. Examining the income side of the welfare equation, the results show that the poorest households lose both in 
terms of wages and agricultural income. In summary, even if trade liberalization has produced beneficial effects across all income groups, at the same time, income inequality has risen as richer households have gained more both in absolute and percentage terms.

Since trade liberalization favors particular endowments relative to others, and since those endowments are unlikely to be evenly across regions, figure 5.3 illustrates the welfare effects for each of the 32 Mexican states. ${ }^{33}$

All the states have benefited from the trade liberalization process of the 1990s, but to different degrees. The states that have benefited the most from trade liberalization are the ones near the United States border, especially the states close to the California border. While regions closer to the Texas border have also greatly benefited, but to a slightly lesser extent. Large beneficiaries are also some of the states in the northern region, such as Aguascalientes, Durango, San Luis Potosi and Nayarit. Virtually all of the states in the central region, with the exception of those immediately surrounding Mexico City, have experienced a welfare gain between 2 and 4 percent, while the urban area of Mexico City gained around 4.5 percent. Finally, trade liberalization has produced the most modest gains for southern states, where welfare effects are in most cases lower than 2 percent.

The results of equation (5.1) produces welfare changes for each household, hence a further way to explore the results is to examine if some particular class of households may have benefited more or less from trade liberalization. To do so, the percentage gains or losses of each household are regressed on a series of variables. The estimation takes the form:

$$
d v_{h}=\beta X_{h}+\gamma C_{h}+\left(\psi_{r}+\eta_{h r}\right)
$$

\footnotetext{
${ }^{33}$ ENIGH data is not collected to be representative at the state level. To produce welfare aggregate at the regional and state level in this paper the average level of expenditure and income shares by state are assumed to reflect those of the underlying population.
} 
where $X_{h}$ is a vector of household and individual characteristics, $C_{h}$ is a vector of control variables, and the term in parentheses is a i.i.d error term with states fixed effect. Specifically, education and gender of the household head, household size, and a dummy for urban areas are included as regressors. Since it has been shown that income is a strong determinant of the percentage gains in welfare, the logarithm of household income is included as a control variable. The estimation uses a fixed effect approach to control for idiosyncratic components at the state level.

The results, shown in table 5.1, illustrate which groups of households or individuals are relatively advantaged in reaping the benefits of trade liberalization. The results indicate that while the effect is no different between male- and female-headed households, education is a strong determinant of the distribution of the gains from trade liberalization. Each additional year of education of the household head corresponds to an average increase in the gains of about 0.21 percent. Urban households also have substantial advantage over rural households ( 0.35 percent) while the effects for age and households size are minimal.

Finally, I explore the extent to which trade liberalization has affected poverty levels. To do so, figure 5.4 illustrates the density function of the log of per capita expenditure as observed in the year 2000 and as it would be if Mexico had kept its tariffs at the level of 1989.

The fact that the observed density lies to the right of the estimated one is evidence of first order stochastic dominance. In other words, poverty levels have declined for any poverty line. Since the integral below the density and to the left of the poverty line corresponds to the poverty headcount index, density functions are useful to illustrate poverty effects. In 2000 about 43 percent of the Mexican population lived in poverty (poverty line about 880 pesos per month or about 100 US dollars). ${ }^{34}$ If Mexico had not liberalized its markets

\footnotetext{
34 COMISIÓN ECONÓMICA para AMÉRICA LATINA y el CARIBE (CEPAL), 2001, Panorama social de América Latina 2000-2001, Santiago de Chile.
} 
during the 1990s, it would have experienced a poverty level of 46 percent. In a country of about 100 million people this means that about 3 million individuals have been lifted out of poverty as a direct effect of the trade liberalization of the 1990s.

\section{Concluding Remarks}

This study performs an ex-post analysis of the effects of the trade liberalization in Mexico between 1989 and 2000, taking into account the regional differences in the Mexican economy. The effects of trade liberalization are first translated into changes in regional prices and wages. Those estimates are plugged into a farm-household model to estimate the effect on households' welfare.

The findings suggest that trade liberalization has affected domestic prices and labor income differently both across income groups and geographically across the country, hence producing diverse outcomes on different households. Regarding prices, the results indicate that trade liberalization has lowered relative prices of most non-animal agricultural products and, while reducing the cost of consumption, has put pressure on households' agricultural income, so widening the income gap between urban and rural areas. The findings also confirm the hypothesis that trade liberalization has had diverse

effects on labor returns. Skilled workers, for which trade liberalization has produced an increase in wages, have benefited relative to unskilled workers as unskilled wages have in many regions decreased as a result of trade liberalization. These results are consistent with the findings of Hanson (2003), who observed rising returns to skilled labor and widening gap in regional wages as a consequence of NAFTA, and Hanson and Harrison (1999), who identify trade liberalization as a cause of the increasing skilled-unskilled wage gap because of the high trade protection experienced by unskilled labor intensive sectors.

Regarding households' welfare, the results indicate that trade liberalization has had diverse effects on welfare across Mexican households. While all income groups have benefited, richer households have benefited more in both absolute and percentage terms. 
For those richer households, the gains are estimated as an increase of 6 percent in disposable real income, while the gains of poorer households are on the order of less than 2 percent. Similar differences are found in the geographic distribution of the benefits of trade liberalization, with the states closest to the United States border gaining threefolds more relative to the least developed states to the south. Therefore trade liberalization, although beneficial, has contributed to inequality. From a poverty perspective, the trade liberalization that occurred between 1989 and 2000 has had the direct effect of reducing poverty by about 3 percent, therefore lifting approximately 3 million individuals out of poverty. 


\section{References:}

Campa, J. M. and L. S. Goldberg (2002). "Exchange Rate Pass-Through into Import Prices: A Macro or Micro Phenomenon?" NBER Working Papers 8934, National Bureau of Economic Research, Inc

COMISIÓN ECONÓMICA para AMÉRICA LATINA y el CARIBE (CEPAL), (2001), Panorama social de América Latina 2000-2001, Santiago de Chile.

Deaton, A. and J. Muellbauer. (1980). Economics and Consumer Behavior. Cambridge: Cambridge University Press.

Deaton, A. (1997). The Analysis of Household Surveys. A Microeconometric Approach to Development Policy, The World Bank and The Johns Hopkins University Press.

Edmonds, E. and N. Pavcnik (2003). "The Effect of Trade Liberalization on Child Labor", mimeo, Darthmund College.

Feenstra, R. C. (1989), "Symmetric Pass-through of Tariffs and Exchange Rates under Imperfect Competition", Journal of International Economics. 27: 27-45.

Feenstra R. and Hanson G., (1997). "Productivity Measurement and the Impact of Trade and Technology on Wages: Estimates for the U.S., 1972-1990," NBER Working Papers 6052, National Bureau of Economic Research, Inc

Goldberg P. and M. Knetter. (1997). "Good Prices and Exchange Rates: What Have We Learned?”, Journal of Economic Literature; 35:1243-1272.

Goldberg, P. and N. Pavcnik (2003). "The Response of the Informal Sector to Trade Liberalization," Journal of Development Economics, forthcoming.

Hanson G. (1997). "Increasing Returns, Trade and the Regional Structure of Wages", The Economic Journal; 440, 113-133.

Hanson G and Harrison A. (1999). "Who Gains from Trade Reform? Some Remaining Puzzles," NBER Working Papers 6915, National Bureau of Economic Research, Inc

Hanson G. (2003). "What happened to Wages in Mexico Since NAFTA?" NBER Working Papers 9563, National Bureau of Economic Research, Inc

Hadri, Kaddour. (2000) "Testing for stationarity in heterogeneous panel data". The Econometrics Journal, 3, 2000, 148-161

Hsiao C. (1986). Analysis of panel data. Cambridge ; New York : Cambridge University Press. 
Ianchovichina, E., A. Nicita, and I. Soloaga, (2001) "Trade Reform and Poverty: The Case of México," World Economy; 25, 945-972.

de Janvry, A., M. Fafchamps, and E. Sadoulet. (1991). "Peasant Household Behavior with Missing Markets: Some Paradoxes Explained," Economic Journal 101:1400-17.

Leamer E. (1996). "Wage inequality from international competition and technological change: theory and country experience" American Economic Review; 86, 2:309-14.

Lustig, N. y M. Székely. (1997). México: Evolución Económica, Pobreza y Desigualdad. Proyecto Programa de Naciones Unidas Para el Desarrollo (PNUD) / Banco Interamericano de Desarrollo (BID) / Comisión Económica para América Latina y el Caribe (CEPAL). Mimeo.

Krugman, P. (1991). "Increasing Returns and Economic Geography” Journal of Political Economy 99:483-99.

Larson, D. (2002). "Exchange rate pass-through and domestic price transmission:

Methodology and application.” OECD Global Forum On Agriculture: Agricultural Trade Reform, Adjustment And Poverty, Paris, 23-24 (May), CCNM/GF/AGR(2002)9

McCulloch, N., A. Winters and X. Cirera .(2002). Trade liberalization and poverty: a handbook. CEPR London.

Nicita A. (2004). "Efficiency and Equity of a Marginal Tax Reform: Income, Quality and Price Elasticities for Mexico", World Bank Policy Research Working Papers, forthcoming.

Taylor E. and I. Adelman (1996) Village economies : the design, estimation, and use of village wide economic models. Cambridge ; New York : Cambridge University Press.

Porto, G. (2003). "Trade Reforms, Market Access and Poverty in Argentina” World Bank Policy Research Working Papers, forthcoming.

Reimer, J. J. (2002). "Estimating the Poverty Impacts of Trade Liberalization" World Bank Policy Research Working Papers No. 2790.

Revenga, A. (1997) "Employment and Wage Effects of Trade Liberalization: The Case of Mexican Manufacturing" Journal of Labor Economics; 15, S20-S43

Robertson, R. (2000). "Wage shocks and North American labor-market integration" American Economic Review (U.S.); 90, No. 4:742-64 
Rodriguez, F. and D. Rodrik. (1999) “Trade Policy and Economic Growth: a Skeptic's Guide to the Cross-National Evidence", NBER Working Papers 7081, National Bureau of Economic Research, Inc

Singh, I., L. Squire and J. Strauss, eds. (1986). Agricultural Household Models, Extensions, Applications and Policy. The World Bank and The Johns Hopkins University Press.

Taylor, J.E. and I. Adelman. (1996). Village Economies: The Design, Estimation, and Use of Villagewide Economic Models. Cambridge University Press.

Topel R. H. (1986). "Local labor markets" Journal of Political Economy; 94, Part 2:S111-S143

Valdés, A. (2002). "Agricultural price distortions and price transmission in developing and transition countries." OECD Global Forum On Agriculture: Agricultural Trade Reform, Adjustment And Poverty, Paris, 23-24 (May), CCNM/GF/AGR(2002)7.

Winters, L. A. (2002). “Trade liberalisation and poverty: what are the links?" World Economy (U.K.); 25, No. 9:1339-67.

Yang J. (1997) "Exchange rate pass-through in U.S. manufacturing industries" Review of Economics and Statistics; 79:95-104

Yunez-Naude A. (2002). "Lessons from NAFTA: The Case of Mexico's Agricultural Sector". World Bank Report. 


\section{APPENDIX A: Data.}

\section{A.1 Data Sources.}

Most of the data utilized in this study come from a series of Encuesta de Ingresos y Gastos de los Hogares (ENIGH), collected by the Instituto Nacional de Estadistica Geografica e Informatica (INEGI), and conducted in the third quarters of 1989, 1992, 1994,1996,1998 and 2000. ENIGH is a rich households survey built for the purpose of measuring the consumption and earnings of Mexican households. Even if the size of the ENIGH has been varying year to year, and its questionnaire updated from survey to survey, the conceptual framework remain the same. This ensures that ENIGH's results are comparable across years. The survey is stratified according to urban and rural location. The sampling is done to assure that households are representative of geographic clusters with probability of being included proportional to cluster size. All the standard errors in the results are corrected for survey design.

The income data and especially the consumption data are very disaggregated. The survey reports 43 income categories subdivided into monetary, non-monetary and financial income. The consumption data consist of more than 600 different entries, about half of which are food items. Food and manufacturing products and services are finely disaggregated.

Since household size is not the same across income levels, and because the welfare measures are concerned with the well-being of individuals, all data were converted to a per capita basis. Since the measure of individual welfare still doesn't have a firm theoretical and empirical basis for the construction of equivalence scales, this paper adopts the standard practice of dividing household income and expenditure by its residents, with children of age 14 or less counting as half of adults. The measure of total household income is equal to the summation of financial, monetary and non-monetary income. Non-monetary income includes payment in kind, gifts and imputed value of rent and self-consumption. Each classification of expenditures and income was converted on a quarterly basis and adjusted for regional inflation using as deflator the official consumer 
price index calculated by Banco de Mexico. The discrimination between skilled and unskilled individuals is based on their level of education. Individuals with less than 9 years of education and without industry specific training are considered unskilled. Earnings have been converted in a hourly basis to make them comparable across individuals and household surveys. In-kind income and self-consumption were included in the measure of total households expenditures, income and welfare.

The matching between the finely disaggregated classification and the product aggregates utilized in this study has been done on the base of Ianchovicina, Nicita and Soloaga, 2002. Detailed concordance tables are available from the author on request.

The results of this paper are differentiated by state (entidad federativa). Figure A.1 illustrates the 32 states and their grouping in 5 regions.

\section{A.2 Variable construction.}

\section{A.2.1 Variable construction for the Pass-through price estimation.}

In estimating equation the distance variable is given by the driving distance between the capital of each state and the United States border. The United States border is defined as the cities Tijuana, Ciudad Juarez and Nuevo Laredo.

International prices indexes are calculated using commodity prices for agricultural products obtained by FAO and the World Bank. For manufacturing products, I utilize US price indexes by commodity published by the Bureau of Labor Statistics.

Local supply is constructed as the production of that particular good that is produced by all the households in the state, in percentage term over all total agricultural production. 
For manufacturing, local supply is calculated as the percentage of individuals working in that particular manufacturing sector for each state. Therefore:

Agricultural Local Supply $_{r g t}=\frac{\sum_{h} P_{h r g t}}{\sum_{h} P_{h r t}} ;$ Manufacturing Local Supply ${ }_{r g t}=\frac{\sum_{i} E_{i r g t}}{\sum_{i} E_{i r t}}$

where $h$ is households and $P$ represent production; and $i$ is individual and $E$ represent earnings.

Regional income is the average level of expenditure of the households in the state $r$. As:

Regional Income ${ }_{r t}=\sum_{h} Y_{h r t} / H_{r t}$

Finally, the tariff is the import weighted average tariff for each of the product aggregates. That is:

$\operatorname{Tariff}_{g t}=\sum_{g} t_{H S} I_{H S} / \sum_{g} I_{H S}$

where $I$ represent imports and $H S$ is the Harmonized System classification codes matched to product group $g$.

\section{A.2.2 Variable construction for the price-wage elasticities.}

The estimation of equation 3.14 is performed with the prices of the 8 agricultural product group aggregated into a single good. The aggregation is weighted by consumption shares such as:

$$
p_{\text {agric }}=\sum_{g} p_{g} s h_{g}, \text { where } \sum_{g} s h_{g}=1
$$


where $p$ is the price of agricultural good $g$ and $s h$ is the share of the expenditure for good $g$, and for the sake of simplicity the subscript for region and time are omitted.

Estimation of equation 3.14 includes several control variables. As in the case of estimation of equation 3.11 the Regional income variable is given by the average level of expenditure of all household in region r. Hence,

Regional Income $_{r t}=\sum_{h} Y_{h r t} / H_{r t}$

where $Y_{h r t}$ is the expenditure of households $h$ in region $r$ at time $t$, and $H_{r t}$ is the number of households in region $h$ at time $t$.

Agricultural Worker is a dummy variable that takes the value 1 if the worker reported agriculture as his main sector of employment and 0 otherwise.

Permanent Employment is a dummy variable that takes the value 1 if the worker reports that his or her type of employment is not temporary and 0 otherwise.

Households Head is a dummy variable that takes the value 1 if the worker is listed as households head and 0 otherwise.

Education Premium is a categorical variable that takes value 1 if the workers completed secondary education and 2 if the workers completed college education, otherwise it takes the value 0 .

Age is the age of the worker in years.

Local Endowment is the sum of individuals in the region that have the same skill of the worker. 
Gender is a dummy variable that takes the value 1 if the worker is male and 0 otherwise.

\section{A.2.3 Variable construction in the welfare decomposition regression.}

The results of the welfare decomposition exercise are illustrated in table 5.3. In the estimation I have the following variables.

Age is the age of the worker in years.

HH_size is the number of individuals in the households

Urban is a is a dummy variable that takes the value 1 if the household resides in urban area and 0 otherwise.

Gender is a dummy variable that takes the value 1 if the household head is male and 0 otherwise.

Logpcexp is the logarithm of per capita expenditure

$E d u c$ is the number of year of schooling.

State Name $(x)$ is a dummy variable that takes value 1 in the case that the household resides in state $(\mathrm{x})$. 


\section{APPENDIX B - The Effect of Trade Liberalization on Prices and Wages, Additional} Results.

This appendix utilized the pass-through elasticites and the price-wage elasticities in a simulation exercise to assess-- the actual effect of trade liberalization upon prices and wages.

\section{B.1 The effect of trade liberalization on prices.}

To obtain the difference between the actual prices observed and the hypothetical prices in the case of no trade liberalization, I utilize the results from equation 3.13.

Equation 3.13 measures the effect on domestic prices in various regions as a consequence of a change in the border prices. Therefore the difference in prices due exclusively to the trade liberalization between 1989 and 2000 can be written as:

$$
\Delta P=P_{\text {observed }}-P_{\text {observed }}(1+d p)
$$

where $d p$ represents the percentage change in the prices due to trade liberalization, and $P_{\text {observed }}$ represents the prices as observed from the year 2000 household survey. The subscripts for region and goods are omitted for the sake of simplicity.

Table B.1 reports the percentage change in prices of the twelve product aggregates due to trade liberalization. For explanatory purposes, results are aggregated at the national level and for five regions (United States border, North, Center, Mexico City, South).

Results indicate that trade liberalization has had the effect of decreasing the relative prices of 9 out of the 12 product aggregates, while the prices of the other 3 product aggregates remained unaffected by the change in tariffs. In other words, without the price effect of trade liberalization, we would have observed higher prices for 9 product aggregates. Of the 12 product aggregates under scrutiny, I will illustrate the effect of 
trade liberalization first on the prices of agricultural products, and then on the price of manufactured goods.

The effect on prices brought about by trade liberalization depends ultimately upon the extent to which trade in each sector is liberalized. During the period from 1989 to 2000, Mexico liberalized agriculture, but not substantially. The average agricultural tariff fell from about 12 percent in 1989 to about 6 percent in 2000. Despite this widespread liberalization, some of the most important agricultural sectors remain largely protected by quotas and other non-tariff barriers. In particular, sectors that are extremely important in the Mexican economy, such as dairy products, meat and maize ${ }^{35}$, have only marginally experienced effective trade liberalization. ${ }^{36}$ The effect of trade liberalization depends also on local supply. For some products, such as legumes and vegetables, local supply covers the large part of consumption, and therefore it is unlikely that internationally set prices will substantially affect local markets. Given these facts, I would expect only a small change in the prices of agricultural products as a consequence of trade liberalization.

An examination of the specific agricultural sectors reveals that the price of cereals, represented mostly by maize, has been only marginally affected by trade liberalization. Without trade liberalization, the price of cereals would have been only about 0.1 percent higher than what was observed in 2000. Since the imported cereals originated mostly from the US, is not surprising that border regions are the only beneficiaries of trade liberalization. The change in tariffs failed to transmit any price movement to the regions far from the border, probably due to high transport costs and increased competitive pressure from local production and imperfect substitution between imported and locally produced corn. ${ }^{37}$

\footnotetext{
${ }^{35}$ Production of maize in Mexico represents 66 percent of total agricultural output in value terms. It also occupies 62 percent of the total cultivated surface. It is estimated that 2.5 to 3 million producers are directly engaged in the production of maize in Mexico.

${ }^{36}$ From 1989 to 2000 the tariff for dairy products was constant around 11 percent, for meat it went from 10 to 8.7 percent, while the tariff for cereals went from 9.2 to 3.7 percent.

${ }^{37} \mathrm{An}$ important issue for the maize market in Mexico is quality. Imported corn, which is almost $100 \%$ of the yellow variety and comes from US, is used mainly as animal feed. The corn used for domestic consumption is of the white variety, which is produced mostly for self-consumption by subsistence and small farmers.
} 
Dairy products are still largely protected in the Mexican economy. Therefore, since trade liberalization has not taken place in the dairy industry, it is not surprising that there is no effect on the prices of dairy products. The average tariff for this product aggregate oscillated between 10 and 11 percentage points during the 1990s. Furthermore, imports of dairy products are very small compared to total consumption, and domestic prices are likely to rely mostly on supply from regional and local markets. Similarly, the prices of meat products have not been affected by trade liberalization, due to the relatively small change in tariff during the period of analysis and due also to the fact that Mexico's imports of meat cover less than five percent of domestic consumption.

In the case of legumes, even though the tariff was reduced from 10 percent to almost 0 percent by 1996, this reduction in tariff failed to produce any effect on prices. The likely reason is that local production dominates the economy. Imports constitute only about 2 percent of total consumption of legumes. Although legumes constitute an important item in the consumption basket of Mexican households, in many cases the legumes are produced and consumed within the same household. Furthermore, Mexican households tend to favor locally produced legumes (Yundez-Naude, 2002).

The tariff for fruit decreased substantially during the 1990s (from about 20 percent in 1989 to about 3 percent in 2000). At the same time, imports of fruits, mostly from other Central American countries, soared from about 90 million dollars in 1989 to more than half a billion dollars in 2000. Results indicate that if tariffs were to be the same as those in 1989, the price of fruit would be about 11 percent higher in 2000. At the regional level, southern areas that are closer to the ports of entry of fruit products registered a higher effect in prices (about 12.5 percent).

A similar argument can be made in the case with vegetables, for which the price would have been about 9.5 percent higher without trade liberalization. Similar to fruit, a larger effect is estimated for the southern regions (about 13 percent). 
Among the other agricultural products, the price of oils and fats, would have been about 7 percent higher without trade liberalization, with a larger effect in the southern regions, while the price of sugar would have been about 6 percent higher without trade liberalization. In the case of sugar, differences across regions are minimal, due to the fact that its price is partly administered.

In the case of the prices of manufacturing products, the effects of trade liberalization are generally larger due to higher rates of pass-through, larger import penetration, and higher tariff liberalization. The average tariff on manufacturing was reduced from about 18 percent to less than 5 percent from 1989 to 2000 . More than 80 percent of manufacturing imports originate from the United States. Volume of imports rose from less than 10 billion dollars in 1989 to more than 100 billion in 2000. Given those facts, one would expect a substantial effect on domestic prices from trade liberalization in the manufacturing sector.

The results indicate that in the case of processed food products, prices would have been about 10 percent higher without the consequences of trade liberalization. Regions closer to the United States border benefited more from trade liberalization (11 percent versus 7 percent in most southern regions). Similarly, in the case of household equipment, trade liberalization was estimated to reduce prices of an average of about 7 percent. Also in this case, the regions closer to the United States border experienced a larger decrease in prices than did southern regions.

Trade liberalization produced a substantially smaller effect in the case of textiles and apparel and other manufacturing products. For textiles, the effect of trade liberalization is approximated to be a 4 percent decrease in prices, while the prices of other manufacturing products were reduced by about 5 percent. As in all manufacturing sectors, the regions closer to the Mexico-US border took larger advantage of trade liberalization in terms of price decrement.

\section{B.2 Effect on wages:}


To retrieve the effect on wages from the change in prices induced by trade liberalization, I utilize the results on the effects of trade liberalization on prices of section 4.1 and the effect on prices on wages of section 4.2.

In this setup the effect on wages is simply given by:

$$
d w_{r(s, u)}=\sum_{g} \beta_{g r s} d p_{g r}
$$

where $d w_{r(s, u)}$ represents the percentage change in the wage in region $r$ of skilled (s) or unskilled (u) individuals, $\beta_{\text {grs }}$ is the price-wage elasticities for skilled and unskilled wages for good $g$ in region $r$, and $d w_{g r}$ is the percentage change in price.

Table B.2 summarizes the estimated effect of trade liberalization to the labor income of skilled and unskilled individuals in the five regions. Skilled wages have increased in four of the five regions, while unskilled wages increased in three of the five regions. Wages in the border, northern and central regions have increased for both skilled and unskilled workers, while in the Mexico City area and in the southern states unskilled wages have declined.

More specifically, skilled wages have increased by 3.5, 5.3 and 2.9 percent in the border, northern and central regions respectively while unskilled wages have increased by 0.6 , 4.4 and 1.1 percent. In the case of the Mexico City area, skilled wages increased about 4.4 percent as a result of trade liberalization while unskilled wages decreased by about 3.8 percent. In the southern regions, mostly dominated by rural agriculture, trade liberalization did not have any effect on skilled wages. Unskilled wages have decreased by about 2.8 percent, mostly driven down by the lower prices of agricultural products. In all regions skilled wages have increased more than unskilled wages. 
Results at the national level on skilled and unskilled wages are obtained weighting the regional averages by the respective number of workers. The results indicate that trade liberalization through its effect on prices has produced an increase of skilled wages by about 3.2 percent and a decrease in unskilled wages of about 0.2 percent. As a result, the wage premium of skilled individuals has increased with trade liberalization, hence contributing to the rise of inequality. These results are in line with the ones obtained by other studies (as in Hanson and Harrison 1999 and Revenga 1997) which systematically find a widening wage gap between skilled and unskilled wages and an increase in the wages in the border region more than elsewhere. 


\section{TABLES AND FIGURES}

Figure 2.1 - Mexico's degree of Openness

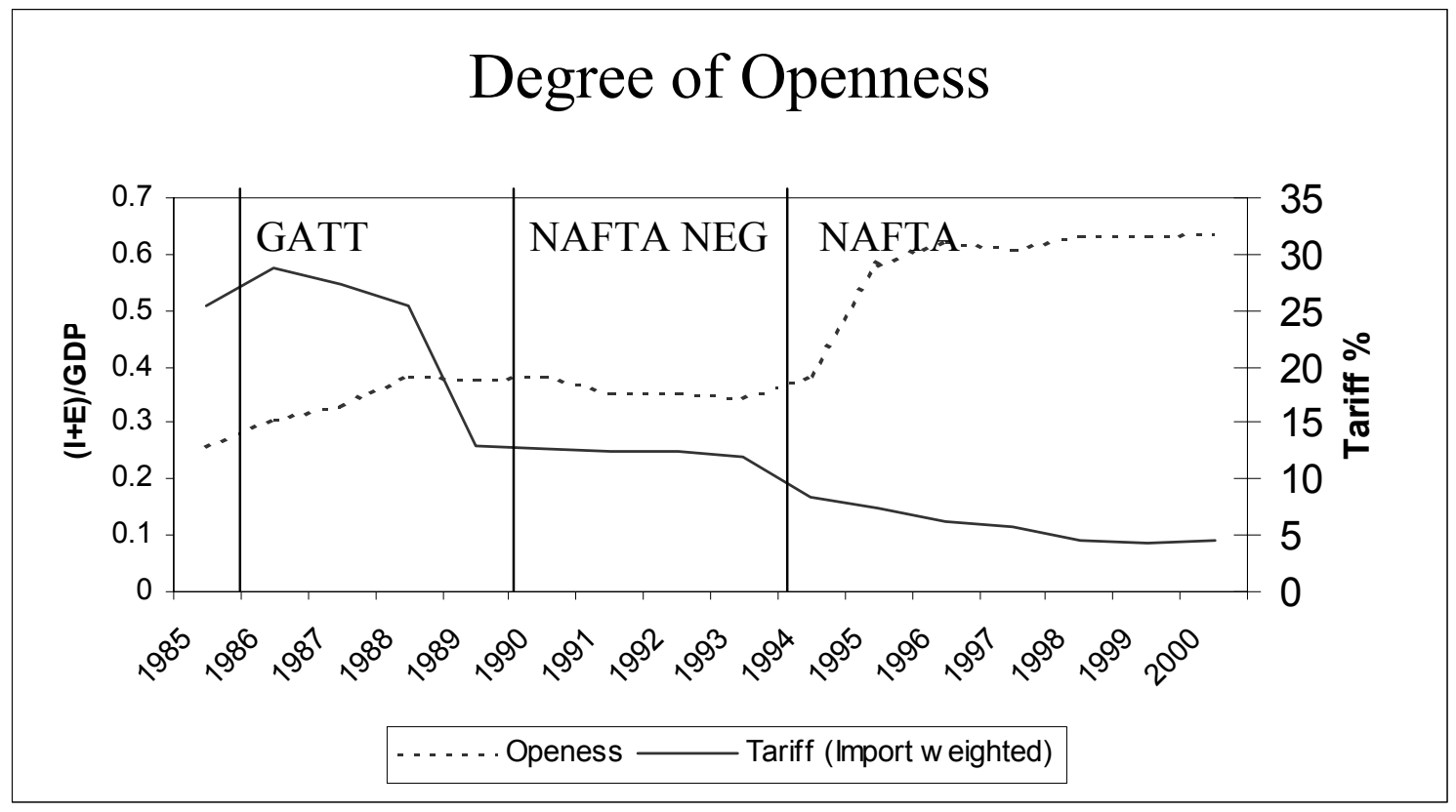

Source: World Development Indicators, World Bank. 
Table 2.1 - Real Prices Movement $(1989=1)$

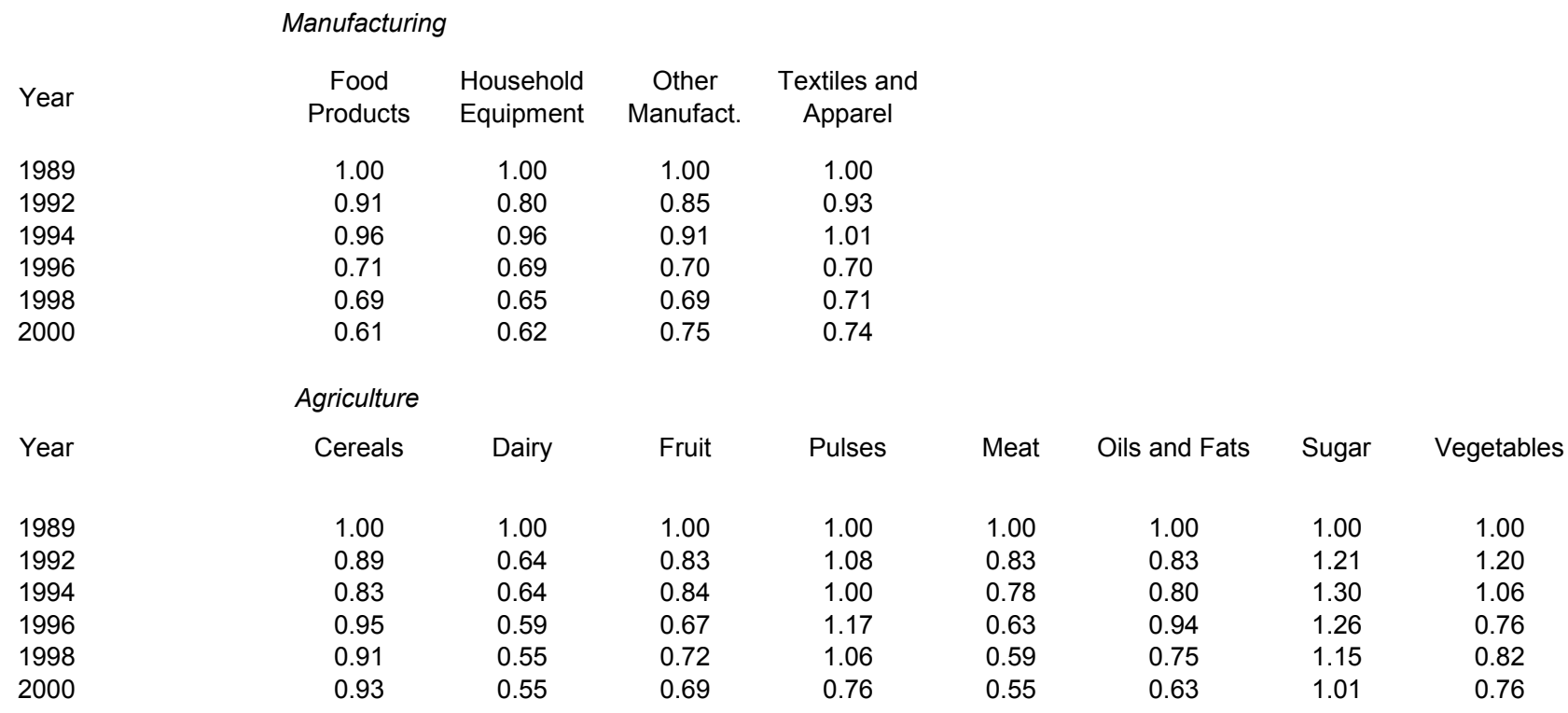

Source: Author's calculation based on INEGI households surveys, 1989-2000.

Table 2.2 - Mexico Average Import Tariff (in percentage)

\begin{tabular}{|c|c|c|c|c|c|c|c|c|c|}
\hline \multirow[b]{2}{*}{ Year } & \multicolumn{3}{|c|}{ Manufacturing } & \multirow[b]{2}{*}{$\begin{array}{c}\text { Other } \\
\text { Manufact. }\end{array}$} & \multirow[b]{2}{*}{$\begin{array}{c}\text { Textiles and } \\
\text { Apparel }\end{array}$} & & & & \\
\hline & $\begin{array}{c}\text { Average } \\
\text { Tariff }\end{array}$ & $\begin{array}{c}\text { Food } \\
\text { Products }\end{array}$ & $\begin{array}{l}\text { Household } \\
\text { Equipment }\end{array}$ & & & & & & \\
\hline 1989 & 12.89 & 15.1 & 14.1 & 10.5 & 19.7 & & & & \\
\hline 1992 & 12.50 & 14.6 & 13.1 & 12.1 & 19.8 & & & & \\
\hline 1994 & 8.56 & 11.6 & 4.9 & 8.3 & 18.0 & & & & \\
\hline 1996 & 6.12 & 9.0 & 3.2 & 6.5 & 14.0 & & & & \\
\hline 1998 & 4.49 & 5.7 & 1.7 & 4.1 & 10.0 & & & & \\
\hline \multirow[t]{3}{*}{2000} & 4.58 & 3.9 & 0.9 & 2.5 & 6.0 & & & & \\
\hline & & Agriculture & & & & & & & \\
\hline & & Cereals & Dairy & Fruit & Pulses & Meat & Oils and Fats & Sugar & Vegetables \\
\hline 1989 & & 9.22 & 10.9 & 19.9 & 10.0 & 10.0 & 11.4 & 12.8 & 7.2 \\
\hline 1992 & & 8.39 & 10.3 & 19.9 & 10.0 & 10.0 & 12.0 & 15.0 & 9.7 \\
\hline 1994 & & 8.31 & 11.1 & 12.9 & 0.1 & 10.0 & 10.4 & 13.1 & 1.7 \\
\hline 1996 & & 7.25 & 11.2 & 8.2 & 0.1 & 10.0 & 7.9 & 8.5 & 0.7 \\
\hline 1998 & & 5.45 & 10.7 & 4.4 & 0.1 & 9.5 & 5.5 & 7.1 & 0.4 \\
\hline 2000 & & 3.71 & 11.5 & 3.4 & 0.1 & 8.7 & 3.4 & 4.6 & 0.3 \\
\hline
\end{tabular}

Source: Author's calculation based on tariff data from TRAINS and COMTRADE. 
Figure 2.2 - Log Real Wages (pesos)

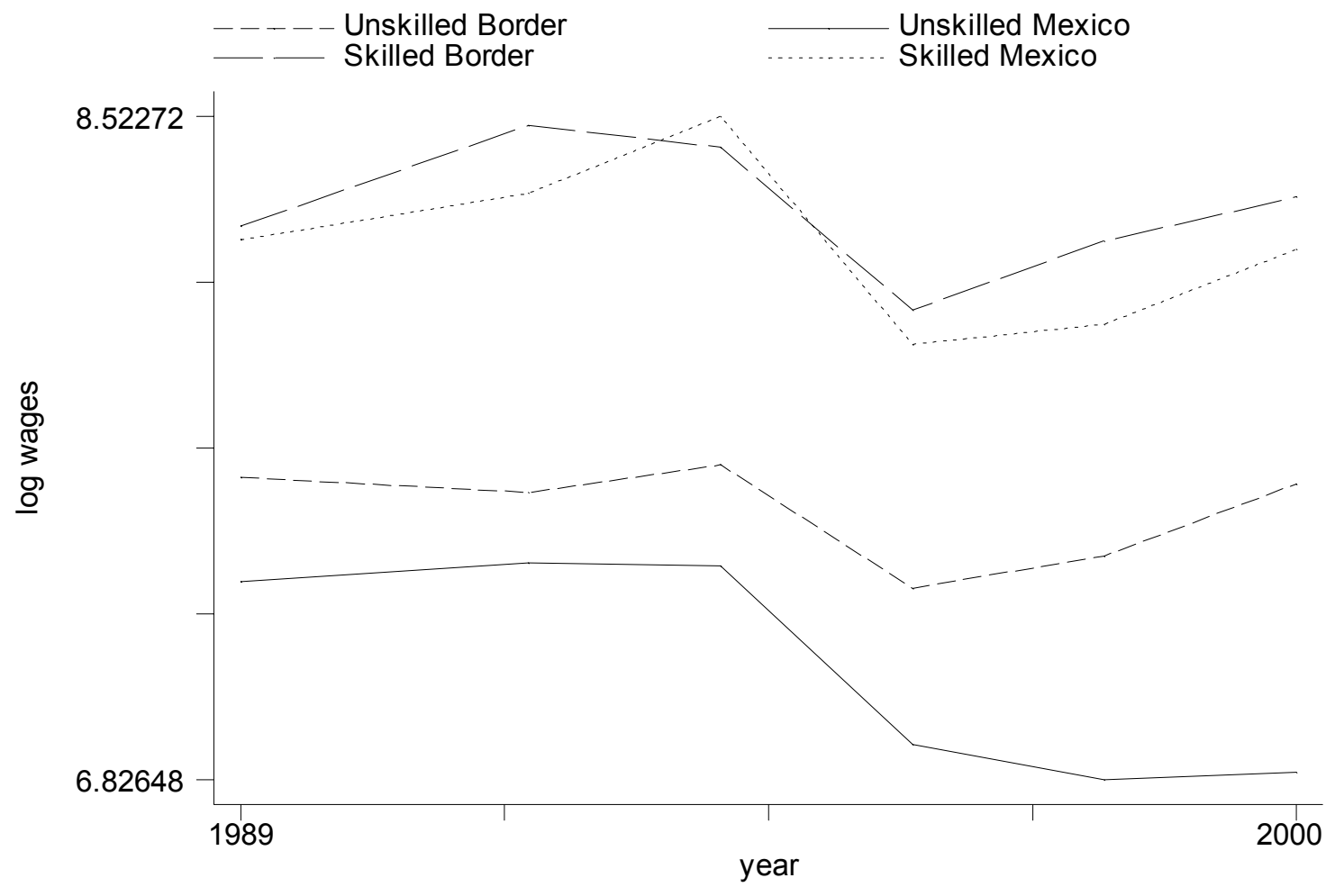

Note: Wages are weighted averages of all education groups using cell sizes as weights. Border wages are the one observed in the 6 border states, Mexico wages are the wages observed in the remaining 26 states. Source: Author's calculation based on tariff data from INEGI households surveys, 1989-2000. 
Table 4.1 - Regression Results: Pass-through Price Elasticities.

Depentent variable - Log of domestic price.

\begin{tabular}{|c|c|c|c|c|c|c|c|c|}
\hline \multicolumn{9}{|c|}{ Agricultural Products } \\
\hline Variable & Cereals & Dairy & Fruit & Pulses & Meat & Oils and Fats & Sugar & Vegetables \\
\hline Constant & $\begin{array}{c}-4.761^{\star * *} \\
(1.570)\end{array}$ & $\begin{array}{c}6.999^{* * *} \\
(1.902)\end{array}$ & $\begin{array}{c}-1.776^{*} \\
(0.914)\end{array}$ & $\begin{array}{c}22.709^{* * *} \\
(2.319)\end{array}$ & $\begin{array}{c}11.326^{* * *} \\
(1.187)\end{array}$ & $\begin{array}{c}5.565^{\star \star *} \\
(0.479)\end{array}$ & $\begin{array}{c}1.417^{\star * *} \\
(0.516)\end{array}$ & $\begin{array}{l}-0.764 \\
(1.663)\end{array}$ \\
\hline Distance & $\begin{array}{l}-0.005 \\
(0.017)\end{array}$ & $\begin{array}{c}-0.046^{* * *} \\
(0.017)\end{array}$ & $\begin{array}{c}-0.027^{\star *} \\
(0.012)\end{array}$ & $\begin{array}{l}0.015 \\
(0.010)\end{array}$ & $\begin{array}{c}0.028^{\star \star *} \\
(0.009)\end{array}$ & $\begin{array}{l}-0.004 \\
(0.006)\end{array}$ & $\begin{array}{c}-0.021^{* * *} \\
(0.008)\end{array}$ & $\begin{array}{r}-0.012 \\
(0.012)\end{array}$ \\
\hline International Price & $\begin{array}{c}0.168^{\star \star \star} \\
(0.059)\end{array}$ & $\begin{array}{c}2.123^{\star * *} \\
(0.346)\end{array}$ & $\begin{array}{l}0.047 \\
(0.131)\end{array}$ & $\begin{array}{c}4.200^{\star * *} \\
(0.461)\end{array}$ & $\begin{array}{c}1.733^{\star \star \star} \\
(0.103)\end{array}$ & $\begin{array}{c}0.770^{\star \star \star} \\
(0.052)\end{array}$ & $\begin{array}{c}-0.061^{*} \\
(0.036)\end{array}$ & $\begin{array}{l}0.026 \\
(0.257)\end{array}$ \\
\hline Local supply & $\begin{array}{l}0.010 \\
(0.015)\end{array}$ & $\begin{array}{c}-0.012 \\
(0.024)\end{array}$ & $\begin{array}{r}-0.013 \\
(0.011)\end{array}$ & $\begin{array}{c}-0.045^{\star \star *} \\
(0.010)\end{array}$ & $\begin{array}{l}-0.015 \\
(0.009)\end{array}$ & $\begin{array}{l}0.006 \\
(0.004)\end{array}$ & $\begin{array}{c}0.021^{* * *} \\
(0.005)\end{array}$ & $\begin{array}{c}0.042^{* *} \\
(0.017)\end{array}$ \\
\hline Regional CPI & $\begin{array}{c}3.695^{\star * *} \\
(0.671)\end{array}$ & $\begin{array}{c}2.163^{* * *} \\
(0.633)\end{array}$ & $\begin{array}{c}1.919^{* * *} \\
(0.332)\end{array}$ & $\begin{array}{l}-0.084 \\
(0.344)\end{array}$ & $\begin{array}{c}1.039^{* * *} \\
(0.301)\end{array}$ & $\begin{array}{c}0.391^{* *} \\
(0.196)\end{array}$ & $\begin{array}{l}0.150 \\
(0.215)\end{array}$ & $\begin{array}{c}1.737^{\star \star *} \\
(0.430)\end{array}$ \\
\hline Tariff & $\begin{array}{l}0.326^{*} \\
(0.179)\end{array}$ & $\begin{array}{l}0.317 \\
(1.020)\end{array}$ & $\begin{array}{c}0.227^{\star * *} \\
(0.074)\end{array}$ & $\begin{array}{c}-0.979^{* * *} \\
(0.142)\end{array}$ & $\begin{array}{c}-3.175^{\star \star *} \\
(0.580)\end{array}$ & $\begin{array}{c}0.223^{\star * *} \\
(0.056)\end{array}$ & $\begin{array}{c}0.266^{\star \star \star} \\
(0.064)\end{array}$ & $\begin{array}{c}0.144^{\star * *} \\
(0.046)\end{array}$ \\
\hline Tariff*Distance & $\begin{array}{c}-0.171^{* * *} \\
(0.045)\end{array}$ & $\begin{array}{l}0.161 \\
(0.132)\end{array}$ & $\begin{array}{l}0.035^{*} \\
(0.019)\end{array}$ & $\begin{array}{l}0.034 \\
(0.033)\end{array}$ & $\begin{array}{c}-0.027^{*} \\
(0.016)\end{array}$ & $\begin{array}{c}0.063^{* * *} \\
(0.015)\end{array}$ & $\begin{array}{l}0.001 \\
(0.016)\end{array}$ & $\begin{array}{l}0.137 \\
(0.134)\end{array}$ \\
\hline $\begin{array}{l}\text { Observation } \\
\text { R squared }\end{array}$ & $\begin{array}{c}192 \\
0.452\end{array}$ & $\begin{array}{c}192 \\
0.318\end{array}$ & $\begin{array}{c}192 \\
0.439\end{array}$ & $\begin{array}{c}192 \\
0.360\end{array}$ & $\begin{array}{c}192 \\
0.811\end{array}$ & $\begin{array}{c}192 \\
0.757\end{array}$ & $\begin{array}{c}192 \\
0.241\end{array}$ & $\begin{array}{c}192 \\
0.434\end{array}$ \\
\hline Manufacturing $\mathrm{Pr}$ & ucts & & & & & & & \\
\hline Variable & $\begin{array}{c}\text { Food } \\
\text { Products }\end{array}$ & $\begin{array}{l}\text { Household } \\
\text { Appliances }\end{array}$ & $\begin{array}{c}\text { Other } \\
\text { Manufact. }\end{array}$ & $\begin{array}{l}\text { Textiles and } \\
\text { Apparel }\end{array}$ & & & & \\
\hline Constant & $\begin{array}{l}2.103^{*} \\
(1.203)\end{array}$ & $\begin{array}{r}-1.772 \\
(1.081)\end{array}$ & $\begin{array}{c}-4.296^{\star \star *} \\
(0.848)\end{array}$ & $\begin{array}{c}-4.451^{\star \star *} \\
(0.583)\end{array}$ & & & & \\
\hline Distance & $\begin{array}{c}0.035^{\star *} \\
(0.015)\end{array}$ & $\begin{array}{l}0.021 \\
(0.016)\end{array}$ & $\begin{array}{l}-0.004 \\
(0.008)\end{array}$ & $\begin{array}{c}0.026^{\star * *} \\
(0.010)\end{array}$ & & & & \\
\hline International Price & $\begin{array}{l}-0.151 \\
(0.157)\end{array}$ & $\begin{array}{l}0.011 \\
(0.033)\end{array}$ & $\begin{array}{l}-0.015 \\
(0.197)\end{array}$ & $\begin{array}{c}0.020^{\star \star *} \\
(0.005)\end{array}$ & & & & \\
\hline Local supply & $\begin{array}{l}-0.007 \\
(0.013)\end{array}$ & $\begin{array}{l}-0.009 \\
(0.008)\end{array}$ & $\begin{array}{l}-0.022 \\
(0.016)\end{array}$ & $\begin{array}{c}-0.074^{\star * *} \\
(0.013)\end{array}$ & & & & \\
\hline Regional CPI & $\begin{array}{l}0.270 \\
(0.487)\end{array}$ & $\begin{array}{c}3.075^{\star \star *} \\
(0.494)\end{array}$ & $\begin{array}{c}3.577^{\star * *} \\
(0.247)\end{array}$ & $\begin{array}{c}3.824^{\star * *} \\
(0.267)\end{array}$ & & & & \\
\hline Tariff & $\begin{array}{c}1.019^{\star * *} \\
(0.104)\end{array}$ & $\begin{array}{c}0.769^{\star \star * *} \\
(0.133)\end{array}$ & $\begin{array}{c}0.671^{* * *} \\
(0.065)\end{array}$ & $\begin{array}{c}0.546^{* * *} \\
(0.058)\end{array}$ & & & & \\
\hline Tariff*Distance & $\begin{array}{c}-0.123^{\star * *} \\
(0.030)\end{array}$ & $\begin{array}{c}-0.109^{\star *} \\
(0.044)\end{array}$ & $\begin{array}{c}-0.116^{* * *} \\
(0.020)\end{array}$ & $\begin{array}{c}-0.097^{\star * *} \\
(0.014)\end{array}$ & & & & \\
\hline $\begin{array}{l}\text { Observation } \\
\text { R squared }\end{array}$ & $\begin{array}{c}192 \\
0.404\end{array}$ & $\begin{array}{c}192 \\
0.774\end{array}$ & $\begin{array}{c}192 \\
0.769\end{array}$ & $\begin{array}{c}192 \\
0.418\end{array}$ & & & & \\
\hline
\end{tabular}

Note: All variables, except distance, are in log. White corrected standard errors are shown in brackets. Significance level of $1 \%, 5 \%$ and $10 \%$ are indicated by $* * *, * *$ and * respectively. 
Table 4.2 - Price-wage Elasticities

Dependent Variable - Log of wage

\section{Control Variables}

\section{Price - Wage Elasticities}

\begin{tabular}{|c|c|c|c|c|c|c|c|c|}
\hline & & Region & Skill & $\begin{array}{l}\text { Agricultural } \\
\text { Products }\end{array}$ & $\begin{array}{c}\text { Food } \\
\text { Products }\end{array}$ & $\begin{array}{l}\text { Households } \\
\text { Appliances }\end{array}$ & $\begin{array}{c}\text { Other } \\
\text { Manufact. }\end{array}$ & $\begin{array}{c}\text { Textiles and } \\
\text { Apparel }\end{array}$ \\
\hline Regional CPI & $\begin{array}{c}0.327^{* * *} \\
(0.070)\end{array}$ & Border & Skilled & $\begin{array}{l}-0.215 \\
(0.176)\end{array}$ & $\begin{array}{c}-0.481^{* *} \\
(0.196)\end{array}$ & $\begin{array}{c}-0.286^{*} \\
(0.251)\end{array}$ & $\begin{array}{c}0.348^{* *} \\
(0.193)\end{array}$ & $\begin{array}{c}0.409^{* *} \\
(0.175)\end{array}$ \\
\hline Agricultural Worker & $\begin{array}{c}-0.542^{* * *} \\
(0.023)\end{array}$ & Region & Unskilled & $\begin{array}{l}-0.276 \\
(0.256)\end{array}$ & $\begin{array}{c}-0.629^{* *} \\
(0.204)\end{array}$ & $\begin{array}{l}-0.016 \\
(0.291)\end{array}$ & $\begin{array}{l}0.463^{* *} \\
(0.235)\end{array}$ & $\begin{array}{c}0.534^{* *} \\
(0.228)\end{array}$ \\
\hline $\begin{array}{l}\text { Permanent } \\
\text { employment }\end{array}$ & $\begin{array}{c}0.290^{* * *} \\
(0.016)\end{array}$ & Northern & Skilled & $\begin{array}{c}-0.377^{*} \\
(0.271)\end{array}$ & $\begin{array}{l}0.205 \\
(0.166)\end{array}$ & $\begin{array}{c}-0.577^{* * *} \\
(0.238)\end{array}$ & $\begin{array}{l}0.198 \\
(0.145)\end{array}$ & $\begin{array}{l}0.343 \\
(0.149)\end{array}$ \\
\hline Household Head & $\begin{array}{c}0.425^{* * *} \\
(0.014)\end{array}$ & Region & Unskilled & $\begin{array}{c}0.713^{* * *} \\
(0.269)\end{array}$ & $\begin{array}{c}-0.551^{*} \\
(0.173) \\
\end{array}$ & $\begin{array}{r}-0.216 \\
(0.284) \\
\end{array}$ & $\begin{array}{r}-0.265 \\
(0.313) \\
\end{array}$ & $\begin{array}{l}0.174 \\
(0.299)\end{array}$ \\
\hline Age & $\begin{array}{c}0.009^{* * *} \\
(0.001)\end{array}$ & Central & Skilled & $\begin{array}{l}-0.301^{*} \\
(0.255)\end{array}$ & $\begin{array}{l}-0.262 \\
(0.188)\end{array}$ & $\begin{array}{c}-0.335^{\star *} \\
(0.244)\end{array}$ & $\begin{array}{l}0.362 \\
(0.285)\end{array}$ & $\begin{array}{l}0.317 \\
(0.244)\end{array}$ \\
\hline Education Premium & $\begin{array}{c}0.186^{* * *} \\
(0.005)\end{array}$ & Region & Unskilled & $\begin{array}{l}0.082 \\
(0.298) \\
\end{array}$ & $\begin{array}{r}-0.062 \\
(0.225) \\
\end{array}$ & $\begin{array}{c}-0.591^{* *} \\
(0.314) \\
\end{array}$ & $\begin{array}{r}-0.412 \\
(0.271) \\
\end{array}$ & $\begin{array}{c}0.729^{* *} \\
(0.191) \\
\end{array}$ \\
\hline Local Endowment & $\begin{array}{l}0.001^{* * *} \\
(0.000)\end{array}$ & Mexico & Skilled & $\begin{array}{l}0.157 \\
(0.344)\end{array}$ & $\begin{array}{l}0.316 \\
(0.251)\end{array}$ & $\begin{array}{c}-0.920^{\star \star \star} \\
(0.426)\end{array}$ & $\begin{array}{l}-0.065 \\
(0.311)\end{array}$ & $\begin{array}{l}0.532^{\star *} \\
(0.283)\end{array}$ \\
\hline Gender & $\begin{array}{c}0.110^{* * *} \\
(0.013)\end{array}$ & City & Unskilled & $\begin{array}{l}0.223 \\
(0.967) \\
\end{array}$ & $\begin{array}{r}-0.192 \\
(0.210) \\
\end{array}$ & $\begin{array}{l}-0.431 \\
(0.340) \\
\end{array}$ & $\begin{array}{r}-0.716 \\
(0.223) \\
\end{array}$ & $\begin{array}{c}0.791^{* *} \\
(0.239) \\
\end{array}$ \\
\hline Dummy year 1989 & $\begin{array}{c}0.203^{* * *} \\
(0.066)\end{array}$ & Southern & Skilled & $\begin{array}{l}0.032 \\
(0.436)\end{array}$ & $\begin{array}{l}-0.147 \\
(0.221)\end{array}$ & $\begin{array}{c}-0.440^{*} \\
(0.474)\end{array}$ & $\begin{array}{l}0.144 \\
(0.460)\end{array}$ & $\begin{array}{l}0.292 \\
(0.416)\end{array}$ \\
\hline Dummy year 1992 & $\begin{array}{c}0.362^{* * *} \\
(0.056)\end{array}$ & Region & Unskilled & $\begin{array}{c}1.180^{* * *} \\
(0.384)\end{array}$ & $\begin{array}{l}0.474 \\
(0.249) \\
\end{array}$ & $\begin{array}{c}-1.552^{*} \\
(0.365) \\
\end{array}$ & $\begin{array}{l}0.531 \\
(0.451) \\
\end{array}$ & $\begin{array}{r}-0.192 \\
(0.366) \\
\end{array}$ \\
\hline Dummy year 1994 & $\begin{array}{c}5.383^{* * *} \\
(0.731)\end{array}$ & & & & & & & \\
\hline Dummy year 1996 & $\begin{array}{c}0.390^{* * *} \\
(0.039)\end{array}$ & \# of Obse & ervations & 44160 & & & & \\
\hline Dummy year 1998 & $\begin{array}{c}-0.178^{* * *} \\
(0.028)\end{array}$ & R-Squ & lared & 0.458 & & & & \\
\hline Dummy year 2000 & $\begin{array}{c}-0.136^{* * *} \\
(0.042)\end{array}$ & & & & & & & \\
\hline
\end{tabular}

Note: All variables are in log, with the exception of dummies. White corrected standard errors are shown in brackets. Significance level of $1 \%, 5 \%$ and $10 \%$ are indicated by $* * * * *$ and $*$ respectively. 
Figure 5.1 - Change in Households' Welfare, by income percentile.

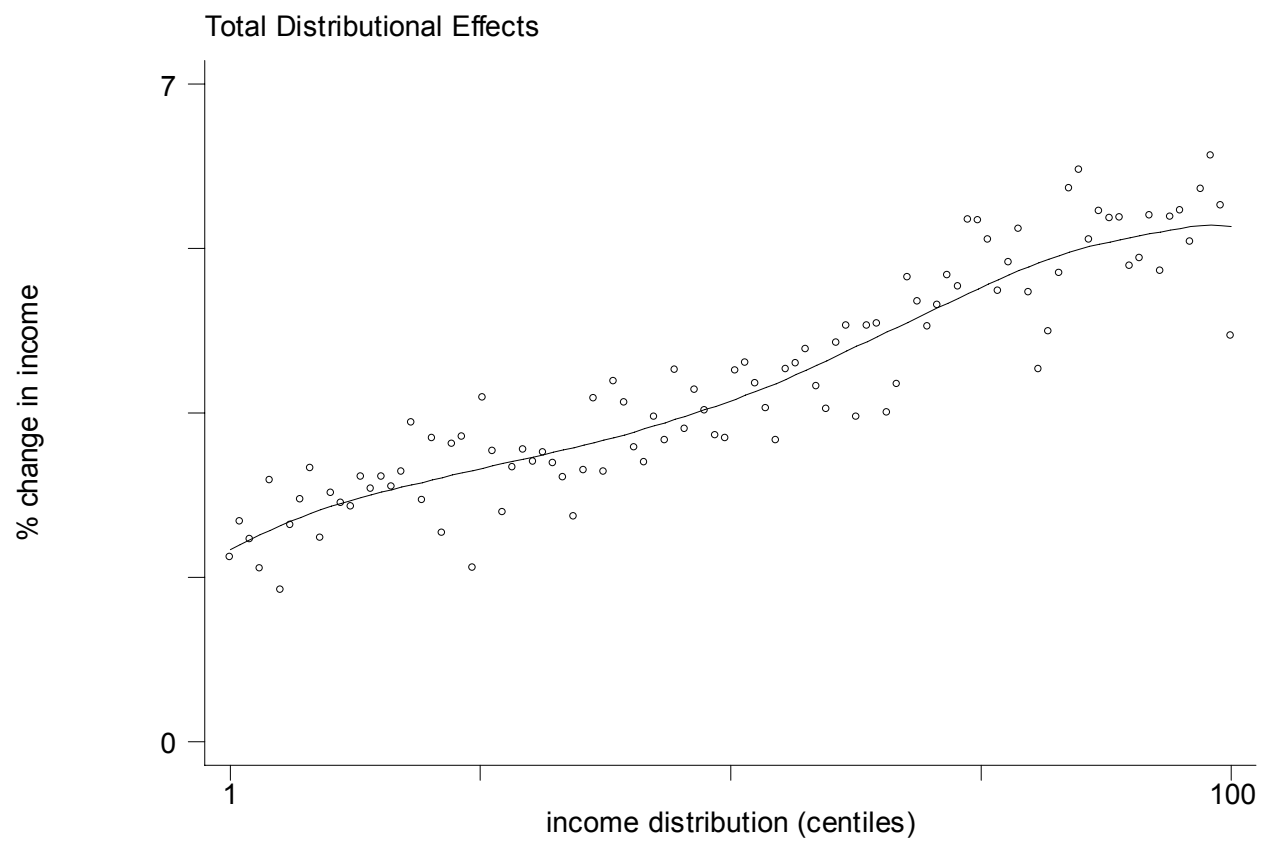

Figure 5.2 - Decomposition of the Change in Households' Welfare.

Fig 5.2a (consumption)
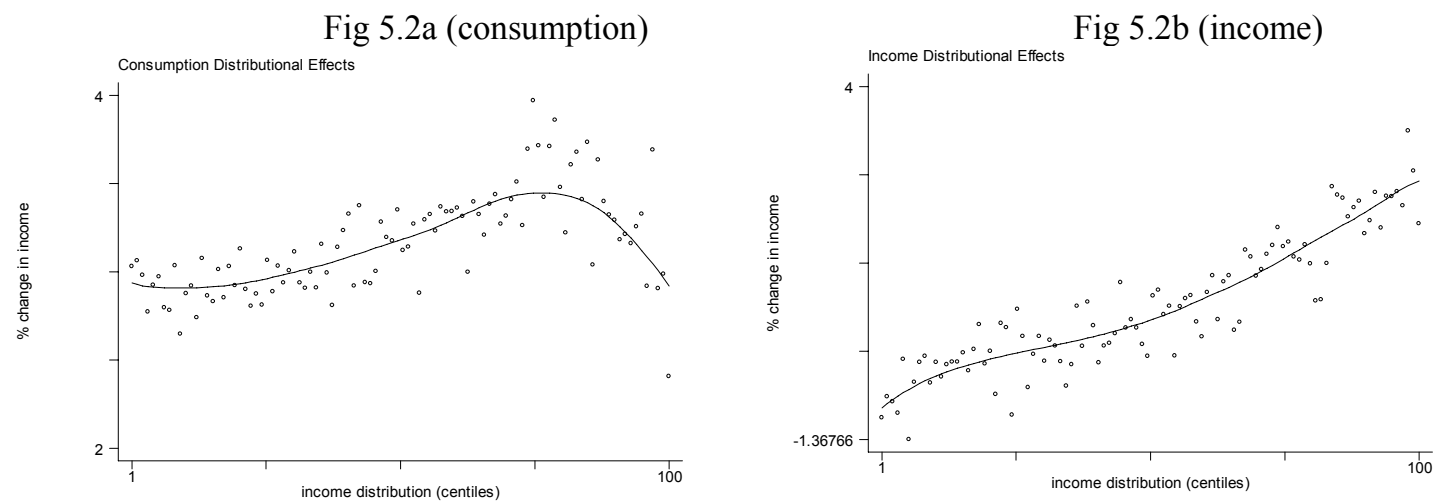

Figure 5.2c (Agric. and Manuf. expenses)

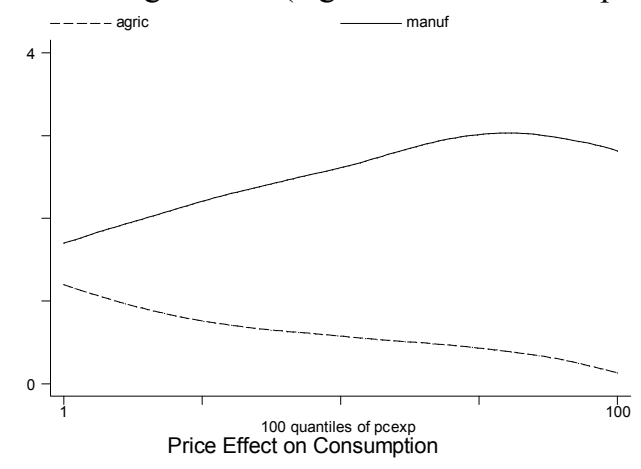

Fig 5.2d (Agric. and Labor income)

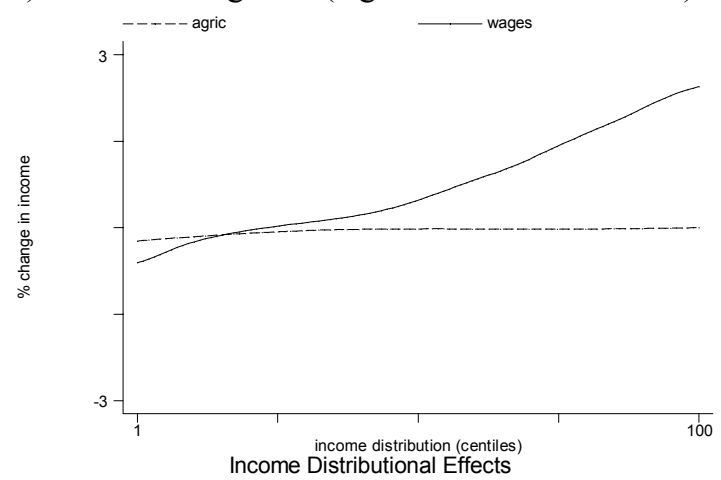


Figure 5.3 - Trade Liberalization and Households Welfare: Regional Effects.

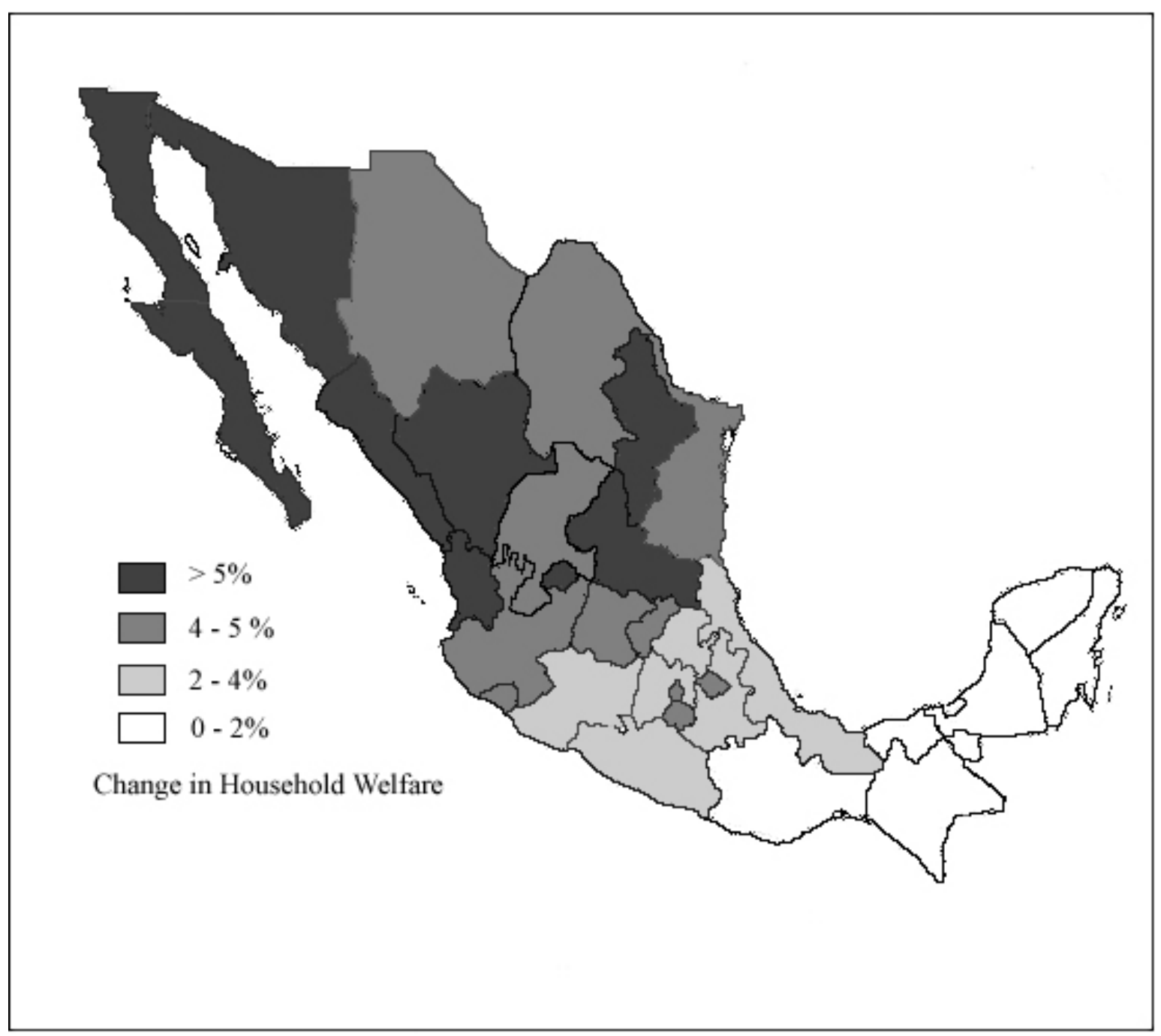


Table 5.1 - Welfare Decomposition by individual and household characteristics Dependent variable: log of welfare change.

\begin{tabular}{|c|c|c|c|c|c|c|c|}
\hline age & $\begin{array}{l}0.0000 \\
(0.0000)\end{array}$ & AGUASCALIENTES & $\begin{array}{c}0.0113^{* * *} \\
(0.0039)\end{array}$ & GUANAJUATO & $\begin{array}{c}-0.0121^{* * *} \\
(0.0033)\end{array}$ & QUERETARO & $\begin{array}{c}-0.0117^{* * *} \\
(0.0037)\end{array}$ \\
\hline educ & $\begin{array}{c}0.0016^{* * *} \\
(0.0001)\end{array}$ & BAJA CALIFORNIA & $\begin{array}{l}0.0042 \\
(0.0034)\end{array}$ & GUERRERO & $\begin{array}{c}-0.0166^{* * *} \\
(0.0033)\end{array}$ & QUINTANA ROO & $\begin{array}{c}-0.0495^{* * *} \\
(0.0038)\end{array}$ \\
\hline gender & $\begin{array}{c}-0.0001 \\
(0.0007)\end{array}$ & $\begin{array}{c}\text { BAJA CALIFORNIA } \\
\text { SUR }\end{array}$ & $\begin{array}{c}0.0159^{* * *} \\
(0.0046)\end{array}$ & HIDALGO & $\begin{array}{c}-0.0116^{* * *} \\
(0.0034)\end{array}$ & SAN LUIS POTOSI & $\begin{array}{c}0.0173^{* * *} \\
(0.0033)\end{array}$ \\
\hline hh_size & $\begin{array}{c}0.0005^{\star * *} \\
(0.0001)\end{array}$ & CAMPECHE & $\begin{array}{c}-0.0412^{* * *} \\
(0.0040)\end{array}$ & JALISCO & $\begin{array}{c}-0.0077^{* *} \\
(0.0032)\end{array}$ & SINALOA & $\begin{array}{c}0.0153^{* * *} \\
(0.0034)\end{array}$ \\
\hline logpcexp & $\begin{array}{c}0.0046^{* * *} \\
(0.0004)\end{array}$ & COAHUILA & $\begin{array}{c}-0.0075^{* *} \\
(0.0034)\end{array}$ & MEXICO & $\begin{array}{c}-0.0361^{* * *} \\
(0.0031)\end{array}$ & SONORA & $\begin{array}{c}-0.0040 \\
(0.0034)\end{array}$ \\
\hline urban & $\begin{array}{c}0.0022^{* * *} \\
(0.0006)\end{array}$ & COLIMA & $\begin{array}{c}-0.0080^{*} \\
(0.0043)\end{array}$ & MICHOACAN & $\begin{array}{c}-0.0112^{* * *} \\
(0.0032)\end{array}$ & TABASCO & $\begin{array}{c}-0.0456^{* * *} \\
(0.0034)\end{array}$ \\
\hline & & CHIAPAS & $\begin{array}{c}-0.0393^{* * *} \\
(0.0031)\end{array}$ & MORELOS & $\begin{array}{c}-0.0152^{* * *} \\
(0.0035)\end{array}$ & TAMAULIPAS & $\begin{array}{c}-0.0091^{* * *} \\
(0.0033)\end{array}$ \\
\hline Obs & 8999 & CHIHUAHUA & $\begin{array}{c}-0.0072^{* *} \\
(0.0033)\end{array}$ & NAYARIT & $\begin{array}{l}0.0028 \\
(0.0038)\end{array}$ & TLAXCALA & $\begin{array}{c}-0.0101^{* * *} \\
(0.0039)\end{array}$ \\
\hline R-Squared & 0.798 & DISTRITO FEDERAL & $\begin{array}{c}-0.0133^{* * *} \\
(0.0032)\end{array}$ & NUEVO LEON & $\begin{array}{c}-0.0060^{*} \\
(0.0033)\end{array}$ & VERACRUZ & $\begin{array}{c}-0.0127^{* * *} \\
(0.0030)\end{array}$ \\
\hline & & DURANGO & $\begin{array}{c}0.0165^{\star * *} \\
(0.0036)\end{array}$ & OAXACA & $\begin{array}{c}-0.0375^{\star * *} \\
(0.0031)\end{array}$ & YUCATAN & $\begin{array}{c}-0.0432^{* * *} \\
(0.0034)\end{array}$ \\
\hline & & & & PUEBLA & $\begin{array}{c}-0.0115^{\star * *} \\
(0.0031)\end{array}$ & ZACATECAS & $\begin{array}{c}0.0144^{* * *} \\
(0.0037)\end{array}$ \\
\hline
\end{tabular}

Note: White corrected standard errors are shown in brackets. Significance level of $1 \%, 5 \%$ and $10 \%$ are indicated by $* * *, * *$ and $*$ respectively. State variables are dummies.

Figure 5.4 - Density Function

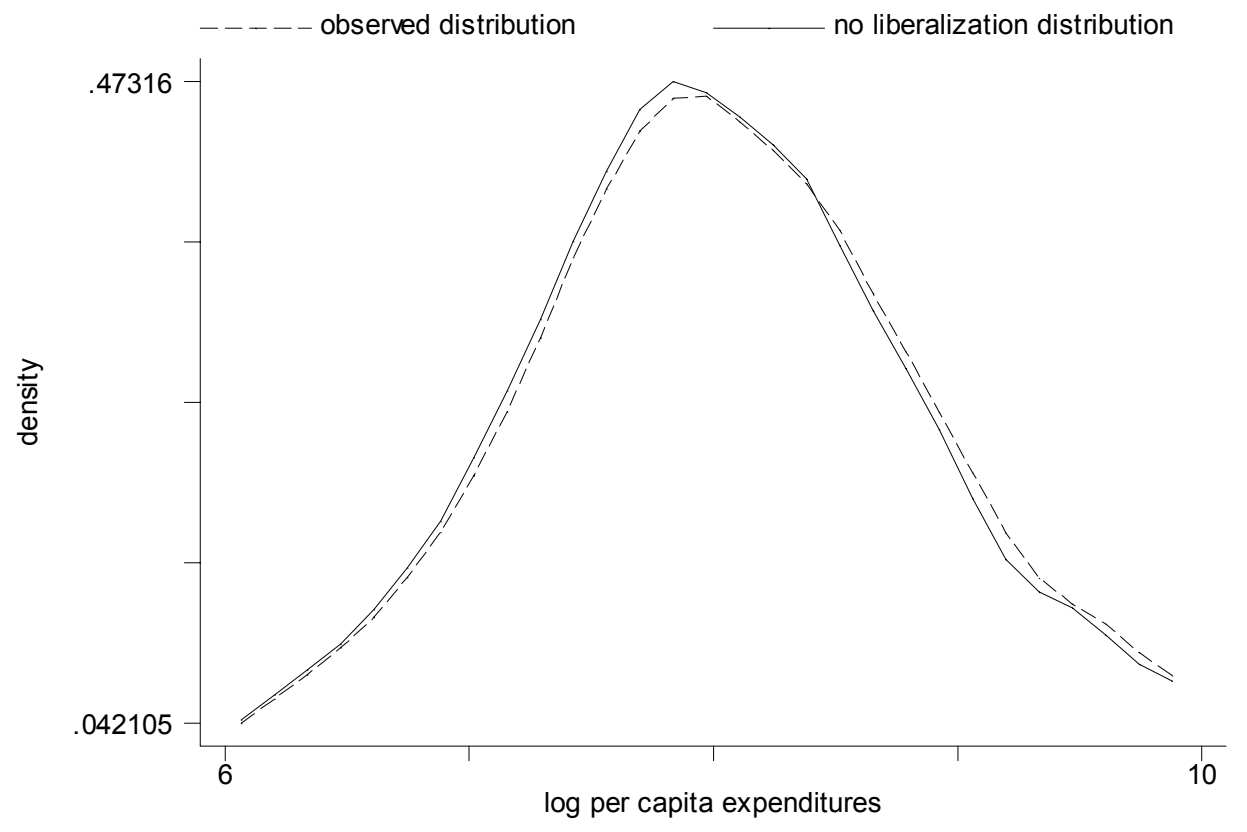


Figure A.1 - Mexico states and regional aggregation.

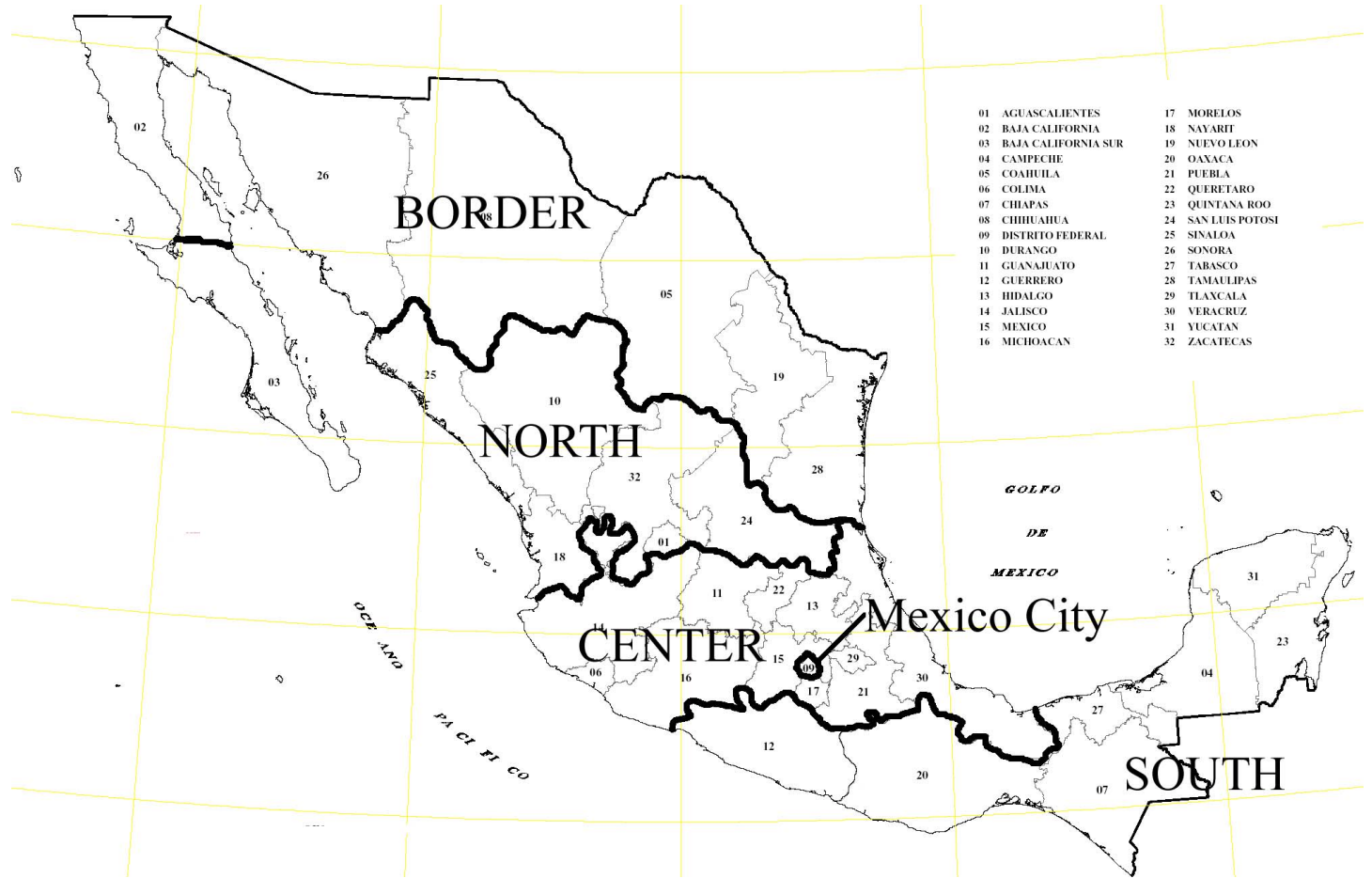


Table B.1 - The Effect of Trade Liberalization on Prices

\begin{tabular}{|c|c|c|c|c|c|c|}
\hline Product & $\begin{array}{l}\text { Country } \\
\text { Average }\end{array}$ & Border & North & $\begin{array}{l}\text { Region } \\
\text { Center }\end{array}$ & Mexico City & South \\
\hline Cereals & $-0.1 \%$ & $-0.3 \%$ & $0.0 \%$ & $0.0 \%$ & $0.0 \%$ & $0.0 \%$ \\
\hline Dairy & $0.0 \%$ & $0.0 \%$ & $0.0 \%$ & $0.0 \%$ & $0.0 \%$ & $0.0 \%$ \\
\hline Fruit & $-11.0 \%$ & $-9.8 \%$ & $-10.7 \%$ & $-11.5 \%$ & $-10.0 \%$ & $-12.6 \%$ \\
\hline Pulses & $0.0 \%$ & $0.0 \%$ & $0.0 \%$ & $0.0 \%$ & $0.0 \%$ & $0.0 \%$ \\
\hline Meat Products & $0.0 \%$ & $0.0 \%$ & $0.0 \%$ & $0.0 \%$ & $0.0 \%$ & $0.0 \%$ \\
\hline Oils and Fats & $-6.9 \%$ & $-6.1 \%$ & $-6.5 \%$ & $-7.4 \%$ & $-6.1 \%$ & $-8.5 \%$ \\
\hline Sugar & $-6.0 \%$ & $-5.9 \%$ & $-6.0 \%$ & $-6.0 \%$ & $-5.9 \%$ & $-6.2 \%$ \\
\hline Vegetable & $-9.4 \%$ & $-7.3 \%$ & $-8.1 \%$ & $-10.4 \%$ & $-7.5 \%$ & $-12.8 \%$ \\
\hline Food Products & $-9.9 \%$ & $-11.3 \%$ & $-10.5 \%$ & $-9.3 \%$ & $-11.2 \%$ & $-7.4 \%$ \\
\hline Households Appliances & $-7.1 \%$ & $-8.6 \%$ & $-8.0 \%$ & $-6.4 \%$ & $-7.5 \%$ & $-4.8 \%$ \\
\hline Other Manufact. & $-5.0 \%$ & $-6.4 \%$ & $-5.8 \%$ & $-4.4 \%$ & $-5.8 \%$ & $-2.8 \%$ \\
\hline Textiles and Apparel & $-4.2 \%$ & $-5.3 \%$ & $-4.8 \%$ & $-3.6 \%$ & $-4.8 \%$ & $-2.3 \%$ \\
\hline
\end{tabular}

Note: This table shows the effect on prices due to the trade liberalization from 1989 to 2000.

Table B.2 - The Effect of Trade Liberalization on Wages

\begin{tabular}{lcccccc} 
Wages & $\begin{array}{c}\text { Country } \\
\text { Average }\end{array}$ & Border & North & $\begin{array}{c}\text { Region } \\
\text { Center }\end{array}$ & Mexico City & South \\
\hline Skilled & $3.2 \%$ & $3.5 \%$ & $5.3 \%$ & $2.9 \%$ & $4.4 \%$ & $0.0 \%$ \\
Unskilled & $-0.2 \%$ & $0.6 \%$ & $4.4 \%$ & $1.1 \%$ & $-3.8 \%$ & $-2.8 \%$
\end{tabular}

Note: This table shows the effect on skilled and unskilled earnings due to the trade liberalization from 1989 to 2000 . 